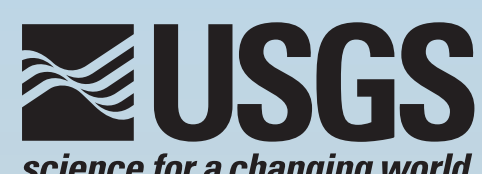

science for a changing world

\title{
Effects of Groundwater Flow on the Distribution of Biogenic Gas in Parts of the Northern Great Plains of Canada and United States
}

Scientific Investigations Report 2010-5251 


\section{COVER}

The Cypress Hills Tertiary remnant, southwestern Saskatchewan and southeastern Alberta, Canada.

Photograph courtesy of Erik Lizee from English Wikipedia. 


\section{Effects of Groundwater Flow on the Distribution of Biogenic Gas in Parts of the Northern Great Plains of Canada and United States}

By Lawrence 0. Anna

Scientific Investigations Report 2010-5251 


\title{
U.S. Department of the Interior \\ KEN SALAZAR, Secretary \\ U.S. Geological Survey \\ Marcia K. McNutt, Director
}

\section{U.S. Geological Survey, Reston, Virginia: 2011}

\author{
For more information on the USGS — the Federal source for science about the Earth, its natural and living resources, \\ natural hazards, and the environment, visit http://www.usgs.gov or call 1-888-ASK-USGS \\ For an overview of USGS information products, including maps, imagery, and publications, \\ visit http://www.usgs.gov/pubprod \\ To order this and other USGS information products, visit http://store.usgs.gov
}

\begin{abstract}
Any use of trade, product, or firm names is for descriptive purposes only and does not imply endorsement by the U.S. Government.

Although this report is in the public domain, permission must be secured from the individual copyright owners to reproduce any copyrighted materials contained within this report.
\end{abstract}

Suggested citation:

Anna, L.O., 2011, Effects of groundwater flow on the distribution of biogenic gas in parts of the northern Great Plains of Canada and United States: U.S. Geological Survey Scientific Investigations Report 2010-5251, 24 p. 


\section{Contents}

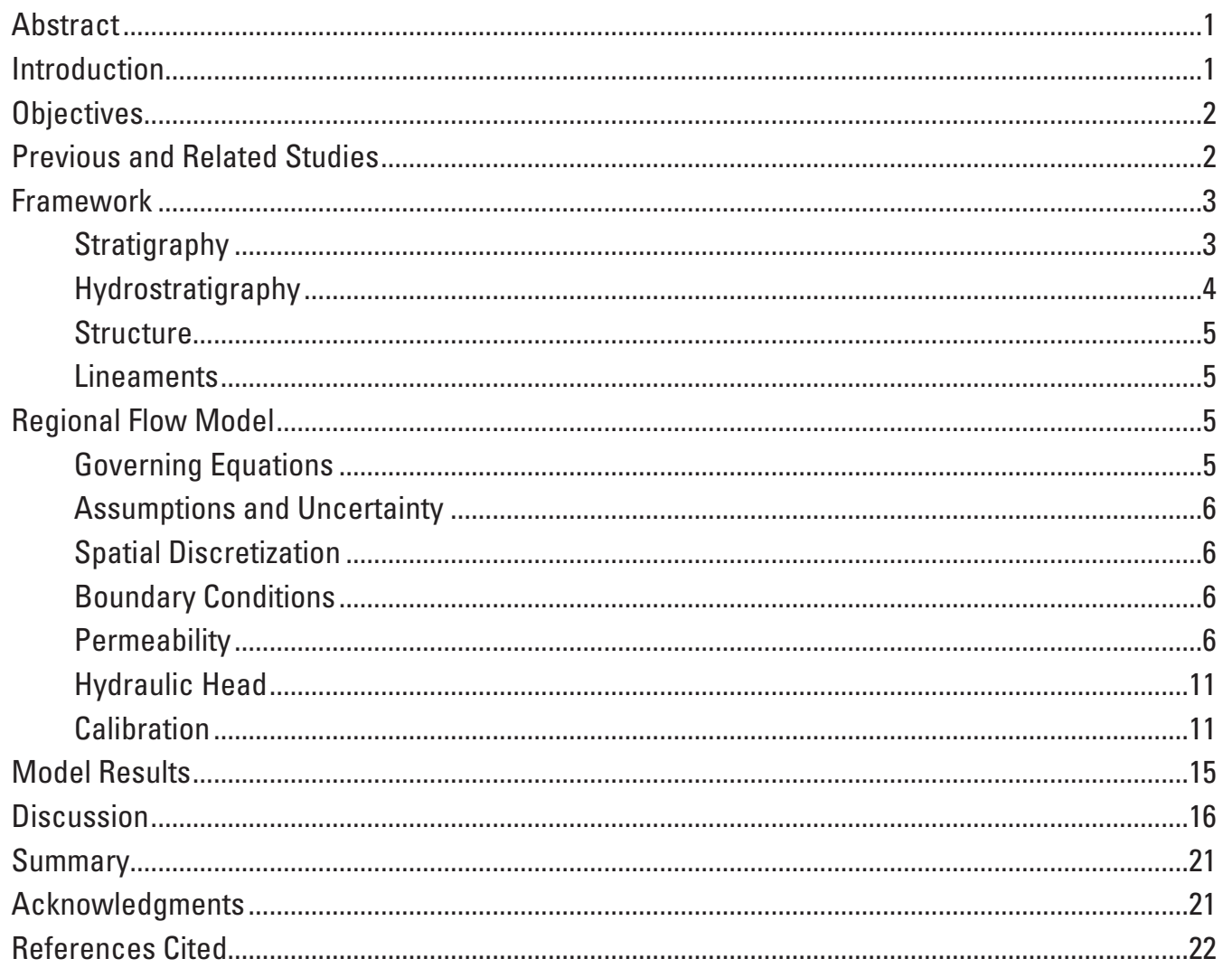

\section{Figures}

1. Map showing the location of the study area ....................................................................

2. Regional stratigraphic section and model layers of selected Cretaceous rocks in Canada and United States ...........................................................................................

3-10. Maps showing:

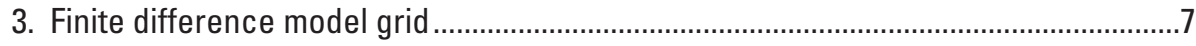

4. Simulated head contours for the Fox Hills aquifer.......................................................

5. Simulated head contours for the Judith River aquifer .................................................8

6. Simulated head contours for the Eagle aquifer.........................................................8

7. Simulated head contours for the Medicine Hat aquifer ...........................................

8. Simulated head contours for the Bowdoin aquifer......................................................

9. Simulated head contours for the Second White Speckled aquifer ............................10

10. Simulated head contours for the Lower Cretaceous aquifer........................................10 
11-17. Maps showing generalized depositional environments of:

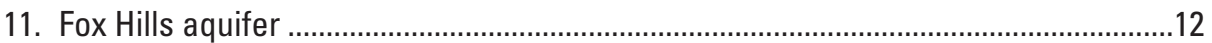

12. Judith River aquifer ................................................................................................12

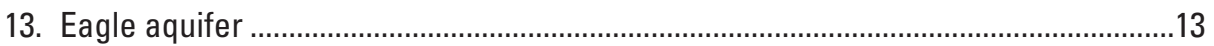

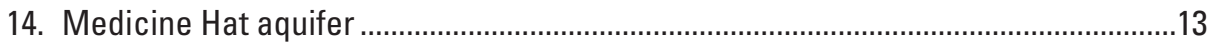

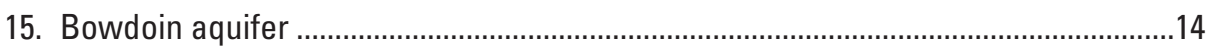

16. Second White Speckled aquifer ........................................................................14

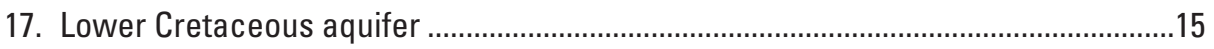

18-21. Diagrams showing:

18. Calibration of hydraulic head in southeast Alberta, Canada ....................................16

19. Conceptual model of a gas trapping mechanism for the Milk River Formation and Medicine Hat Sandstone ..................................................................17

20. Three, two-dimensional cross sections of simulated hydraulic head through gas producing and Tertiary outcrop areas...................................................18

21. Conceptual model of cross-sectional flow across southeast Alberta gas accumulation 19

22. Map showing spatial relations between Tertiary covered remnants and economic biogenic gas fields

\section{Tables}

1. Aquifer and confining layer permeability ranges used in the model .................................5

2. Drill-stem-test derived transmissivity of selected Cretaceous formations in Montana

3. Permeability values cited in the literature and used to help constrain model input

4. Average regional groundwater-flow velocity for model aquifer layers

5. Capillary pressures of the Milk River Formation, Alberta and Saskatchewan, Canada 


\title{
Effects of Groundwater Flow on the Distribution of Biogenic Gas in Parts of the Northern Great Plains of Canada and United States
}

\author{
By Lawrence 0. Anna
}

\section{Abstract}

Parts of the northern Great Plains in eastern Montana and western North Dakota and southeastern Alberta and southwestern Saskatchewan, Canada, were studied as part of an assessment of shallow biogenic gas in Upper Cretaceous rocks.

Large quantities of shallow biogenic gas are produced from low-permeability, Upper Cretaceous reservoirs in southeastern Alberta and southwestern Saskatchewan, Canada. Rocks of similar types and age produce sparingly in the United States except on large structures, such as Bowdoin dome and Cedar Creek anticline. Significant production also occurs in the Tiger Ridge area, where uplift of the Bearpaw Mountains created stratigraphic traps. The resource in Canada is thought to be a continuous, biogenic-gas-type accumulation with economic production in a variety of subtle structures and stratigraphic settings. The United States northern Great Plains area has similar conditions but only broad structural closures or stratigraphic traps associated with local structure have produced economically to date.

Numerical flow modeling was used to help determine that biogenic gas in low-permeability reservoirs is held in place by high hydraulic head that overrides buoyancy forces of the gas. Modeling also showed where hydraulic head is greater under Tertiary capped topographic remnants rather than near adjacent topographic lows. The high head can override the capillary pressure of the rock and force gas to migrate to low head in topographically low areas. Most current biogenic gas production is confined to areas between mapped lineaments in the northern Great Plains. The lineaments may reflect structural zones in the Upper Cretaceous that help compartmentalize reservoirs and confine gas accumulations.

\section{Introduction}

This study was part of a larger project that investigated the occurrence of shallow biogenic gas in Upper Cretaceous rocks of the northern Great Plains (NGP) in eastern Montana (fig. 1) and western North Dakota of the United States, and parts of southeastern Alberta and southwestern Saskatchewan, Canada (fig. 1). Continuous or unconventional gas accumulations account for an increasing share of the total gas produced in the United States.

Large quantities of shallow biogenic gas are produced from low-permeability, Upper Cretaceous reservoirs in southeastern Alberta and southwestern Saskatchewan, Canada. Rocks of similar type and age produce sparingly in the United States except on large structures such as Bowdoin dome in north-central Montana, the Cedar Creek anticline in southeastern Montana, and Tiger Ridge in north-central Montana. The resource in Canada is thought to be a continuous, biogenic gas accumulation with economic production in "sweet spots" that are scattered in a variety of subtle structural and stratigraphic settings. The United States has similar geologic conditions, but for undocumented reasons, only large structural closures have produced economically. There is a spectrum of possible explanations to describe the discrepancy — one or all may be valid.

As part of a multidiscipline effort, a hydrogeologic study was initiated to evaluate the effects of groundwater flow on biogenic gas accumulations. Groundwater flow can affect gas trapping mechanisms, water and gas chemistry, gas migration timing and pathways, and alter the initiation and continuance of biogenic gas generation. Pressure responses controlled by the groundwater system can affect capillary pressure barriers and relative permeability differences between reservoir and seal.

Groundwater flow in low-permeability rock creates unique challenges compared to conventional reservoirs and aquifers that are well defined and categorized in terms of their hydraulic and geometric properties. These rocks typically receive little attention when determining hydraulic properties. Laboratory investigation of low-permeability rock resorts to strained or forced boundary conditions to achieve test results. Extrapolating data from small-scale experiments (core-plug permeability) to large-scale problems continues to be difficult and controversial. Consequently, low-permeability-rock properties are usually assumed and later adjusted to calibrate conceptual or numerical models (Neuzil, 1986). 


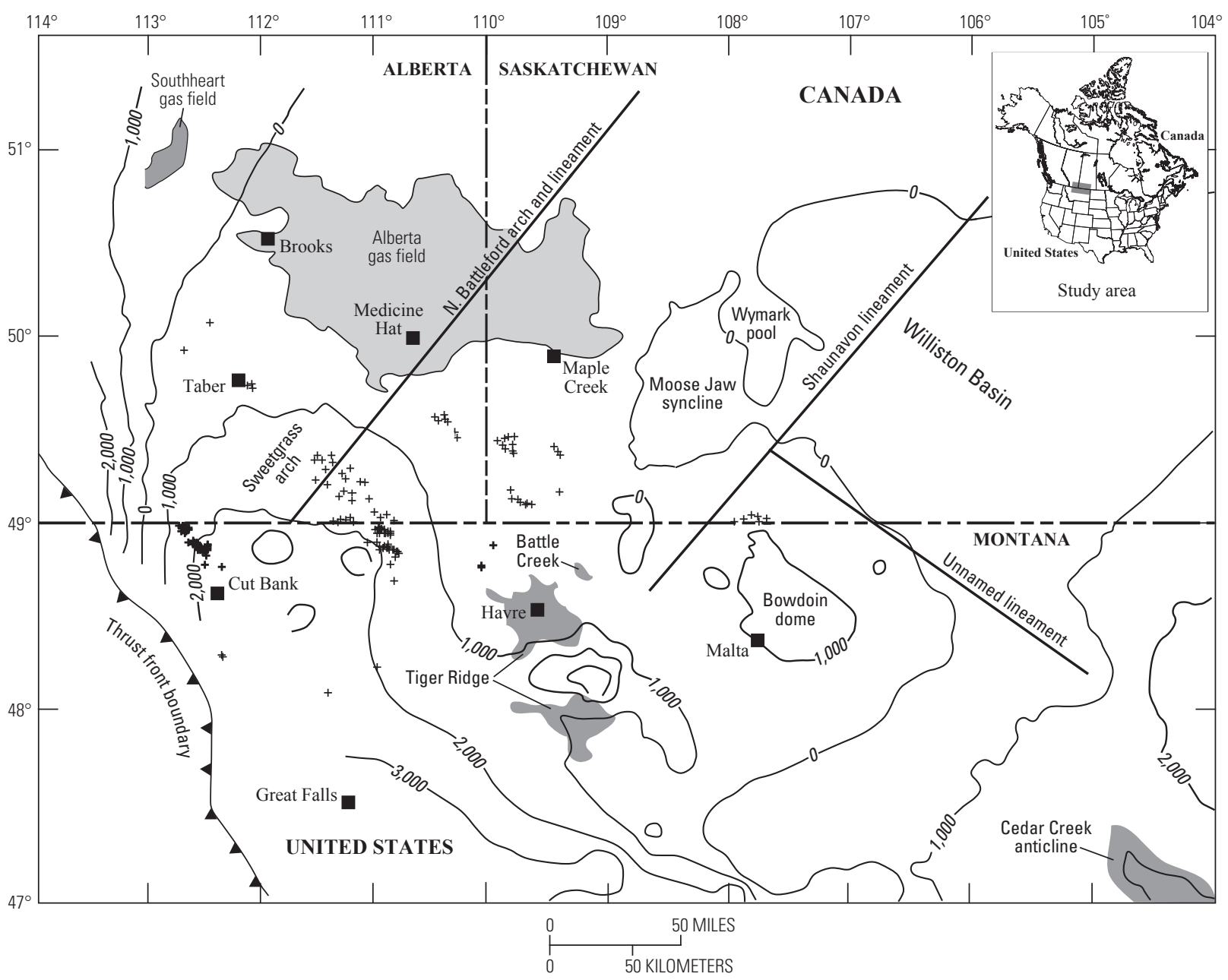

Figure 1. Map showing the location of the study area. Gray areas are gas fields and the symbol + represents producing well locations from a variety of Upper Cretaceous reservoirs. Contour lines are structure contours on top of the Milk River Formation/Eagle Sandstone and equivalents. Contour interval is 1,000 ft.

\section{Objectives}

The primary objective of this study was to determine the role of groundwater flow on the generation, migration, and distribution of biogenic gas and all associated conditions that define continuous-type biogenic gas distributions in parts of the NGP in Upper Cretaceous rocks. Related objectives were to (1) map the basic framework of the reservoirs, aquifers, and confining units to institute a finite difference, multilayered numerical flow model; (2) relate in a broad sense the observed present-day groundwater-flow patterns to present-day biogenic gas distribution; and (3) compare areas of current economic gas production with nonproducing areas.

\section{Previous and Related Studies}

There have been numerous studies on the geology and reservoir characteristics of the Upper Cretaceous section of the NGP region including Masters (1979), Rice and Shurr (1980), Rice (1980, 1984), Nydegger and others (1980),
Mejer-Drees and Mhyr (1981), Shurr (1984), Martin and Young (1991), Berkenpas (1991), Schroder-Adams and others (1997), and Hamblin (1997). Masters (1979) hypothesized and subsequently discovered a deep-basin trap that consisted of an updip water phase in high-permeability sandstone and a downdip gas phase in low-permeability siltstone and silty sandstone. Rice and Shurr (1980) showed that the best environment to generate and preserve shallow biogenic gas was in low-permeability Cretaceous reservoirs. The low-permeability reservoirs consisted of shallow shelf sands, silts, and chalks bounded by marine shales that were both hydrocarbon source and seal. Rice and Shurr (1980) also speculated that lineament block tectonics controlled the location of shelf sandstones and controlled fracture patterns within the shelf sedimentary rocks. MejerDrees and Mhyr (1981) provided a good description of the sedimentation and depositional history of the gas-producing Milk River Formation in southern Alberta; their study was updated by O'Connell (2002). Shurr (1984) described the Shannon Member of the Eagle Sandstone in Montana, 
and Rice (1984) described the physical characteristics of the Mosby Sandstone Member of the Belle Fourche Shale in Montana.

Studies on the geochemistry of biogenic gas formation and distribution include Fuex (1977), Rice and Claypool (1981), Andrews and others (1991), Hendry and others (1991), Drimmie and others (1991), Martini and others (1996), Ridgley and others (1999), Cramer and others (1999), and Lillis (2007). Rice and Claypool (1981) speculated that after uplift and subsequent erosion of the Tertiary section in Canada, early-formed biogenic gas was exsolved and moved by capillary pressure from immature organic-rich shale to shallow-shelf-sandstone reservoirs.

Some of the earlier studies on the theoretical analysis of groundwater systems include Toth (1963) and Freeze and Witherspoon (1966), and specifically in Western Canada include Hitchon (1969) and Magara (1972). Later studies linking gas accumulations with groundwater flow include Hitchon (1984), Downey (1986), Hendry and others (1991), Corbet and Bethke (1992), Lies and Letourneau (1995), and Cramer and others (1999).

Downey (1986) described the groundwater-flow system for the total stratigraphic column of the United States part of the NGP. The report is a good description of the regional hydrogeologic and geochemical system for the Phanerozoic. Hitchon (1969) documented that topography exerts control on regional and local groundwater-flow systems. That is, topographic highs are areas of recharge and topographic lows are areas of discharge. In a subsequent paper, Hitchon (1984) asserted that there is a genetic link between topography, flow paths, and biogenic gas occurrences. He also mapped a major groundwater divide that trends north-northeast from southern Alberta. West of the divide, groundwater flows north discharging at the Athabasca oil sands; east of the divide, groundwater flows eastward into southeast Alberta and southern Saskatchewan. Hitchon (1984) also demonstrated that there was an upward hydraulic potential (gradient) from Lower Cretaceous sandstones to the Upper Cretaceous Second White Speckled sandstone (an informal unit), and minor hydraulic potential between the Milk River and the Medicine Hat Formations. Corbet and Bethke (1992) used models to determine the cause of underpressuring in the area. They reasoned that the underpressuring was due to pore volume expansion because of substantial Pliocene and Pleistocene uplift and erosion. Their model results also showed that Darcy (average) flow velocity decreased during the erosional period because of a gradient reduction, and that the Lower Cretaceous was characterized by anomalously low hydraulic potential. In addition, the hydraulic potential of the Milk River aquifer is still equilibrating to post-glacial conditions due to the formation's low permeability. Levings (1981a, b) included a database of selected drill-stem tests, interpreted data, and other hydrogeological data for Montana. He also published a series of potentiometric maps for a number of Cretaceous aquifers (Levings, 1982a, b, c).

\section{Framework}

The framework for the groundwater-flow system used in the finite difference model was developed using ArgusONE geographic information system (GIS) software, version 4.0.0 (Shapiro and others, 1997). This approach helped compile the framework as map layers that included a finite-difference mesh superimposed over the layer framework. Groundwater flow was simulated using the USGS modular three-dimensional flow code MODFLOW96 (Harbaugh and McDonald, 1996). MODFLOW96 was coupled to ArgusONE as a graphical user interface (GUI; Shapiro and others, 1997).

\section{Stratigraphy}

Cretaceous stratigraphic nomenclature used in this report is shown in figure 2. The use of different names for equivalent units is common for Cretaceous formations in the NGP due to nomenclature differences between the United States and Canada. In addition, each unit comprises several depositional environments of roughly equivalent age, which results in multiple formation and member names.

The NGP was part of a deep and expansive north-south trending seaway during most of Cretaceous time (Gill and Cobban, 1973). Depositional environments associated with the seaway included coastal areas, shorelines, shallow and deep shelf, slope, and basin. The area was punctuated with numerous transgressive and regressive events that controlled sedimentation patterns. Thickness of the Lower Cretaceous section is relatively uniform across the region with mostly shoreline to marginal-marine sandstones to the west transitioning to marine sandstone, siltstone, and shale to the east. Thickness of the Upper Cretaceous section is variable and consists of coastal sandstone, marine shale, and thin shelf sands to the west transitioning to mostly carbonate, chalk, and shale lithologies to the east. The Upper Cretaceous Fox Hills Formation and the overlying Hell Creek Formation sections grade eastward into a regionally extensive regressive sequence of shoreline sandstone and coastal sandstones and mudstones, capped by a Tertiary section of nonmarine fluvial dominated sandstones, siltstones, coals, and mudstones.

The Lower Cretaceous units are composed of a series of shoreline and shallow marine sandstones and siltstones and in places are unconformably overlain by estuarine and fluvial sandstone, siltstone, and shale. Thin but laterally extensive marine shales such as the Fuson Formation and the Skull Creek Shale separate Lower Cretaceous sandstones vertically. Although the regional distribution of sandstone is heterogeneous, the Lower Cretaceous strata function as a single flow system.

Sandstones of the Upper Cretaceous Colorado Group consist of the informal Second White Speckled sandstone and Cardium and Medicine Hat Sandstones and equivalents (fig. 2). These units were deposited in a shallow to deep shelf environment, with coarsening upward successions that 


\begin{tabular}{|c|c|c|c|c|c|c|c|}
\hline System & Series & Stage & & Alberta & Saskatchewan & Montana & Model layers \\
\hline \multirow{15}{*}{ 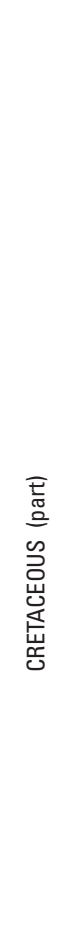 } & \multirow{13}{*}{ 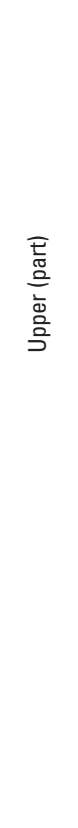 } & $\begin{array}{l}\text { Maastrichtian } \\
\quad \text { (part) }\end{array}$ & \multirow{5}{*}{ 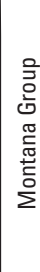 } & Fox Hills Formation & Fox Hills Formation & Fox Hills Formation & Fox Hills aquifer \\
\hline & & \multirow{4}{*}{ Campanian } & & Bear Paw Shale & Bear Paw Shale & Bear Paw Shale & Bearpaw confining \\
\hline & & & & Belly River Formation & Belly River Formation & Judith River Formation & Judith River aquifer \\
\hline & & & & $\begin{array}{l}\text { Pakowki and Lea } \\
\text { Park Formations }\end{array}$ & $\begin{array}{l}\text { Pakowki and Lea } \\
\text { Park Formations }\end{array}$ & Claggett Shale & Claggett confining \\
\hline & & & & Milk River Formation & Milk River Formation & $\begin{array}{l}\text { Eagle Sandstone and } \\
\text { Gammon Shale }\end{array}$ & Eagle aquifer \\
\hline & & \multirow[t]{2}{*}{ Santonian } & \multirow{6}{*}{ 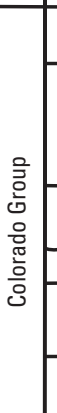 } & $\begin{array}{c}\text { First White } \\
\text { Speckled Shale }\end{array}$ & $\begin{array}{c}\text { First White } \\
\text { Speckled Shale }\end{array}$ & \multirow{3}{*}{ Niobrara Formation } & Gammon confining \\
\hline & & & & $\begin{array}{l}\text { Medicine Hat } \\
\text { Sandstone }\end{array}$ & $\begin{array}{l}\text { Medicine Hat } \\
\text { Sandstone }\end{array}$ & & Medicine Hat aquifer \\
\hline & & Coniacian & & Colorado Shalo & \multirow[b]{2}{*}{$\begin{array}{l}\text { Colorado } \\
\text { Shale }\end{array}$} & & Niobrara confining \\
\hline & & \multirow[t]{2}{*}{ Turonian } & & $\begin{array}{c}\text { Cardium } \\
\text { Sandstone }\end{array}$ & & Carlile Shale & Bowdoin aquifer \\
\hline & & & & $\begin{array}{l}\text { Second White } \\
\text { Speckled Shale }\end{array}$ & $\begin{array}{l}\text { Second White } \\
\text { Speckled Shale }\end{array}$ & $\begin{array}{l}\text { Greenhorn } \\
\text { Formation }\end{array}$ & Greenhorn confining \\
\hline & & \multirow{3}{*}{ Cenomanian } & & $\begin{array}{c}\text { Second White } \\
\text { Speckled sandstone }\end{array}$ & $\begin{array}{c}\text { Second White } \\
\text { Speckled sandstone }\end{array}$ & $\begin{array}{c}\text { Phillips } \\
\text { Sandstone }\end{array}><\begin{array}{l}\text { Mosby } \\
\text { Ss. Mbr. }\end{array}$ & $\begin{array}{l}\text { Second White } \\
\text { Speckled aquifer }\end{array}$ \\
\hline & & & & Belle Fourche Shale & Belle Fourche Shale & Belle Fourche Shale & \multirow[b]{2}{*}{ Mowry confining } \\
\hline & & & & $\begin{array}{l}\text { Fish } \\
\text { Scales } \\
\text { zone }\end{array}$ & Fish Scales zone & Mowry Shale & \\
\hline & \multirow{2}{*}{ 㐫 } & Albian & & $\begin{array}{l}\text { Bow Island Sandstone, Viking } \\
\text { Sandstone, and Joli Fou Formation }\end{array}$ & $\begin{array}{l}\text { Bow Island Sandstone, Viking } \\
\text { Sandstone, and Joli Fou Formation }\end{array}$ & $\begin{array}{c}\text { Muddy and Newcastle Sandstones, } \\
\text { Skull Creek Shale, Fuson Shale, } \\
\text { and Fall River Formation } \\
\end{array}$ & \multirow{2}{*}{$\begin{array}{l}\text { Lower Cretaceous } \\
\text { aquifer }\end{array}$} \\
\hline & & Aptian & & Mannville Group & Mannville Group & Kootenai Formation & \\
\hline
\end{tabular}

Figure 2. Regional stratigraphic section and model layers of selected Cretaceous rocks in Canada and United States. Modified from Rice and Shurr (1980).

prograded seaward and were deposited and preserved in bathymetric lows during a sea level lowstand. The sandstones were probably moderately to heavily bioturbated, disrupting bedding and reducing permeability. During a sea level highstand, shales were deposited over most of the shelf, whereas shoreline and coastal plain sandstones were deposited to the west.

Following deposition of the Colorado Group (fig. 2), the Cretaceous shoreline prograded eastward, where the Eagle Sandstone of the Montana Group was deposited as a regressive-transgressive wedge. The basal regressive unit was an eastwardly prograding shoreline from west to east, overlain by coastal plain deposits. The top transgressive unit represented westerly back-stepping shoreline, back barrier, and tidal flat environments (Rice, 1980; Ridgley, 2000). Similar to the Colorado Group, the Montana Group (fig. 2) units record a relative lowering of sea level and were deposited as shallow to midshelf successions of coarsening upward sands and silts.

Renewed transgression of the Upper Cretaceous seaway created a deep shelf to basin environment as recorded by the Claggett Shale. Later, the Judith River Formation was deposited as a regressive-transgressive wedge, similar to the Eagle Sandstone. The basal regressive unit was an eastwardly prograding shoreline with the transgressive units deposited in westerly back-stepping shoreline, back barrier, and tidal flat environments. The shoreline deposits of the Judith River are characterized by relatively high porosity and permeability, especially in the western part of the study area. West of the shoreline, coastal plain and fluvial deposits are present; to the east, the deposits are shallow to deep marine including coarsening upward sandstone successions. The final transgression during deposition of the Bearpaw Shale left only thin, highly bioturbated sands as a transgressive lag.

The final regression of the Cretaceous seaway resulted in the deposition of the Fox Hills Formation and equivalents as shoreline and barrier deposits from a west to east retreating shoreline. The overlying Hell Creek Formation and equivalents are the coastal plain and fluvial equivalents resulting from the Fox Hills regression.

\section{Hydrostratigraphy}

A hydrostratigraphic unit exhibits similar hydraulic characteristics throughout the unit, acts as a one-flow system regardless of rock type, and is categorized as an aquifer or a confining unit. Hydrostratigraphic units do not necessarily follow formation or succession boundaries. For example, in a coarsening upward succession, as are most Upper Cretaceous shelf deposits, the top part of the depositional cycle is usually the most porous and permeable and qualifies as a reservoir or aquifer. The lower and thicker part of the cycle is less porous and permeable and would qualify as a confining unit.

The NGP hydrostratigraphy can be summarized as (1) aquifers with relative high, uniform permeability and large to moderate areal extent such as the Upper Cretaceous 
shoreline sandstones of the Eagle, Judith River, and Fox Hills Formations, and (2) low-permeability aquifers deposited in a shelf environment with thin and varied extent of reservoir quality sandstone such as the Second White Speckled sandstone, Bowdoin Sandstone, Medicine Hat Sandstone, and parts of the Milk River Formation. Both types of aquifers are important in the total flow system, although this study focused on the low-permeability aquifers and reservoirs.

The 13 hydrostratigraphic layers in the model (table 1, fig. 2) consist of seven aquifer layers, each separated by a confining layer. From bottom to top, the layers are defined as the Lower Cretaceous aquifer, Mowry confining unit, Second White Speckled aquifer, Greenhorn confining unit, Bowdoin aquifer, Niobrara confining unit, Medicine Hat aquifer, Gammon confining unit, Eagle aquifer, Claggett confining unit, Judith River aquifer, Bearpaw confining unit, and the Fox Hills aquifer.

The Lower Cretaceous aquifer was modeled as one system because the individual formations within the aquifer are not target reservoirs for biogenic gas in the NGP, and from the regional model modified from Downey (1986), the Lower Cretaceous aquifer acts as a pressure buffer between underlying Paleozoic units and the overlying Upper Cretaceous and Tertiary units. In addition, Corbet and Bethke (1992) and Hitchon (1984) state that the Lower Cretaceous units function as a pressure sink.

\section{Structure}

Laramide orogenic events at the end of the Cretaceous helped define the Rocky Mountain highlands and intermountain basins and activated major structures in the area, resulting in the present-day structural configuration (fig. 1). During this time, the Cretaceous Western Interior Seaway made its final and complete regression. Major structures of the area influencing the groundwater-flow system include the overthrust belt, the Bearpaw and Little Rocky Mountains, Little Belt uplifts, Sweetgrass arch, the western flank of the

Table 1. Aquifer and confining layer permeability ranges used in the model. Range of values represent variability in rock types.

\begin{tabular}{|c|c|c|c|}
\hline \multirow[t]{2}{*}{ Name } & \multirow[t]{2}{*}{ Layer } & \multicolumn{2}{|c|}{$\begin{array}{c}\text { Permeability/hydraulic } \\
\text { conductivity }\end{array}$} \\
\hline & & feet per day & millidarcy \\
\hline Fox Hills aquifer & 1 & 2.0 & 729 \\
\hline Bearpaw confining layer & 2 & $1.0 \mathrm{E}-05$ & $2.74 \mathrm{E}-0$ \\
\hline Judith River aquifer & 3 & $.026-.25$ & $10-95$ \\
\hline Claggett confining layer & 4 & $1.0 \mathrm{E}-05$ & 2.74E-02 \\
\hline Eagle aquifer & 5 & $.025-.25$ & $7-92$ \\
\hline Gammon confining layer & 6 & $1.0 \mathrm{E}-05$ & $2.74 \mathrm{E}-02$ \\
\hline Medicine Hat aquifer & 7 & $.02-.2$ & $3-73$ \\
\hline Niobrara confining layer & 8 & $1.0 \mathrm{E}-05$ & $2.74 \mathrm{E}-02$ \\
\hline Bowdoin aquifer & 9 & $.005-.05$ & $1.8-73$ \\
\hline Greenhorn confining layer & 10 & $5.0 \mathrm{E}-06$ & $1.37 \mathrm{E}-02$ \\
\hline Second White Speckled aquifer & 11 & $.0001-.1$ & $.036-40$ \\
\hline Mowry confining layer & 12 & $1.0 \mathrm{E}-06$ & 2.74E-03 \\
\hline Lower Cretaceous aquifer & 13 & $.25-.5$ & $90-185$ \\
\hline
\end{tabular}

Williston Basin, and the Bowdoin dome. These features not only create topography but influence aquifer recharge, discharge, and hydraulic gradients.

\section{Lineaments}

There are several major lineaments in the area that may have influenced Cretaceous sedimentation patterns, erosion patterns and locations, and compartmentalization of Upper Cretaceous gas reservoirs in the NGP. Many of the lineaments have roots in Precambrian or Paleozoic rocks and have influenced sedimentation patterns as shown in studies by Thomas (1974), Brown (1978), Gerhard and others (1982), Maughan (1982), Anna (1986), Shurr and Watkins (1992), and Ridgley and others (2001).

\section{Regional Flow Model}

A numerical flow model was developed to determine general effects of the regional groundwater-flow system on the spatial distribution of shallow biogenic gas accumulations. The model was used as a guide to help conceptualize processes governing the migration and trapping of gas. A steady state model simulated present-day conditions, replicating all flow components as if they were in equilibrium, although the system is probably not at true equilibrium due to stress on the system from human activity.

\section{Governing Equations}

The steady state equation for three-dimensional flow used in this study that excludes sources and sinks (Freeze and Cherry, 1979, p. 64) is

$$
\frac{\partial}{\partial x}\left(K_{H} \frac{\partial h}{\partial x}\right)+\frac{\partial}{\partial y}\left(K_{H} \frac{\partial h}{\partial y}\right)+\frac{\partial}{\partial z}\left(K_{Z} \frac{\partial h}{\partial z}\right)=0
$$

where

$$
\begin{aligned}
h \quad= & \text { hydraulic head, }(\mathrm{L}), \\
K_{H} \quad= & \text { horizontal hydraulic conductivity (permeability), } \\
& (\mathrm{L} / \mathrm{T}),
\end{aligned}
$$

and

$$
x, y, z \quad=\text { Cartesian coordinates where } x \text { and } y \text { are horizontal }
$$
and $z$ is vertical (L).

Equation 1 defines the law of conservation of mass for saturated porous media and requires that the rate of fluid mass into a defined volume equals the rate of fluid mass out of the volume.

Equation 1 is solved using MODFLOW96 flow code (Harbaugh and McDonald, 1996) with the preconditioned conjugate gradient method (PCG2; Hill, 1990). 


\section{Assumptions and Uncertainty}

Several assumptions were made to simplify the modeling process and to accommodate data availability: (1) the groundwater-flow system is at steady state implying that pressure distributions for the Upper Cretaceous units are in equilibrium; (2) the permeability distributions were generalized but are assumed to be regionally representative; (3) recharge from precipitation was not considered, except for the top layer, and water was added to all layers using constant head boundaries where formations outcrop, but interformational flow, if any, was part of the modeling process and not artificially prescribed; (4) discharge from the system was prescribed at constant head nodes representing stream base flow at distal ends of the flow system; (5) all stratigraphic data were simplified to accommodate the modeling process, especially thickness; and (6) although the units of permeability are different than hydraulic conductivity, this study assumed that hydraulic conductivity is based on the density of fresh water; therefore, permeability is used interchangeably with hydraulic conductivity, and permeability is preferred for convenience and familiarity with the petroleum community.

Uncertainty associated with this study is qualitative because sufficient data were not available to render a statistical value of uncertainty, and inverse modeling methods were not available. Most of the uncertainty was from (1) generalized permeability values assigned to formations and depositional environments - these were derived from drill-stem-test measurements that probably undersampled the formation; (2) inaccurate facies mapping; (3) few reliable measured heads were available to calibrate the model, and the measurement accuracy was unknown; (4) the model was run at steady state even though the system is probably not at steady state; (5) rebound effects from glaciation were not considered; and (6) recharge and discharge values were assumed to represent true values.

\section{Spatial Discretization}

Lateral model boundaries were extended to help determine a regional concept of the flow system, capture all known low-permeability Upper Cretaceous biogenic gas reservoirs, and to eliminate boundary effects. The eastern boundary was located in the western part of the Williston basin at about $103^{\circ}$ longitude, and the western boundary was the Montana overthrust belt. The northern boundary was several kilometers north of the Medicine Hat gas field in southern Alberta, and the southern boundary was the southern boundary of Montana. The model covered an area of approximately $294,000 \mathrm{mi}^{2}$ $\left(761,000 \mathrm{~km}^{2}\right)$.

Model layers were discretized based on regional time-line stratigraphy. The model was divided vertically into 13 layers with an aquifer and confining layer couplet. Horizontal layers of the model were discretized with a finite difference grid, generated in ArgusONE GIS and coupled with MODFLOW96 (Harbaugh and McDonald, 1996) GUI (Shapiro and others, 1997). The grid cell size was 6 mi per side, and the grid had 81 rows and 101 columns (fig. 3 ).

\section{Boundary Conditions}

Model boundaries were simplified to accommodate generalized geological conditions and to help simplify numerical processes. Constant head boundaries were specified where the aquifer layer outcropped, and its elevation was determined from topographic maps. The model assumed outcrop elevations were at or near the water table. The constant head boundaries were distributed along outcrop traces as shown in figures 4-10. All other cells were general head boundaries.

Although the upper layer was modeled as confined, recharge from precipitation was needed to calibrate the upper layers to observed heads. Constant head boundaries in the upper layer could not provide enough water to the system to match observed heads. Therefore, precipitation recharge of 0.22 in. per year (5.6 mm per year) was applied only to the upper layer (Fox Hills) as a constant value over the entire layer, although total precipitation recharge was a small percentage of total flux. The total water flux through the model at steady state was $4.1 \mathrm{ft}^{3} / \mathrm{s}\left(0.12 \mathrm{~m}^{3} / \mathrm{s}\right)$. The flux seems low when compared with reported flux values calculated from numerical models for Cretaceous basins in the Rocky Mountain area (Belitz and Bredehoeft, 1988). However, Case (1984) reported a flux of $0.7 \mathrm{ft}^{3} / \mathrm{s}\left(0.02 \mathrm{~m}^{3} / \mathrm{s}\right)$ in the Lower Cretaceous aquifer south of the Black Hills, South Dakota. The relatively low flux in the study area is probably the result of the low permeability of the Cretaceous aquifer system compared with the high permeability of the Lower Cretaceous in other basins (Belitz and Bredehoeft, 1988).

\section{Permeability}

All permeability values were derived from the literature or company records. Levings (1981b) reported several calculations of transmissivity (permeability $\times$ thickness) from drillstem tests for Lower and Upper Cretaceous aquifers in eastern Montana (table 2). Berkenpas (1991) reported calculated permeability values for the Milk River Sandstone in Canada. Several publications reported permeability measurements from core plugs, well tests, and simulated values that helped calibrate flow models including Corbet and Bethke (1992), Belitz and Bredehoeft (1988), and Bredehoeft and others (1992) (table 3). There was not a systematic process to analyze the data. Rather, an estimate of the most representative values and trial-and-error methods were used to calibrate the model. Table 1 lists a range of permeability values that were used in the model that reflect various depositional environments. For each layer, depositional environments were mapped in ArgusONE GIS then each environment was assigned a permeability value (figs. 11-17). Permeability values were assigned based on (1) available empirical data for a particular environment, (2) a best guess where environments without data were assigned a permeability value, and (3) fixed values for the confining units as shown in table 1. Permeability exhibited an order of magnitude decrease from top to bottom, reflecting increased lithostatic load. 


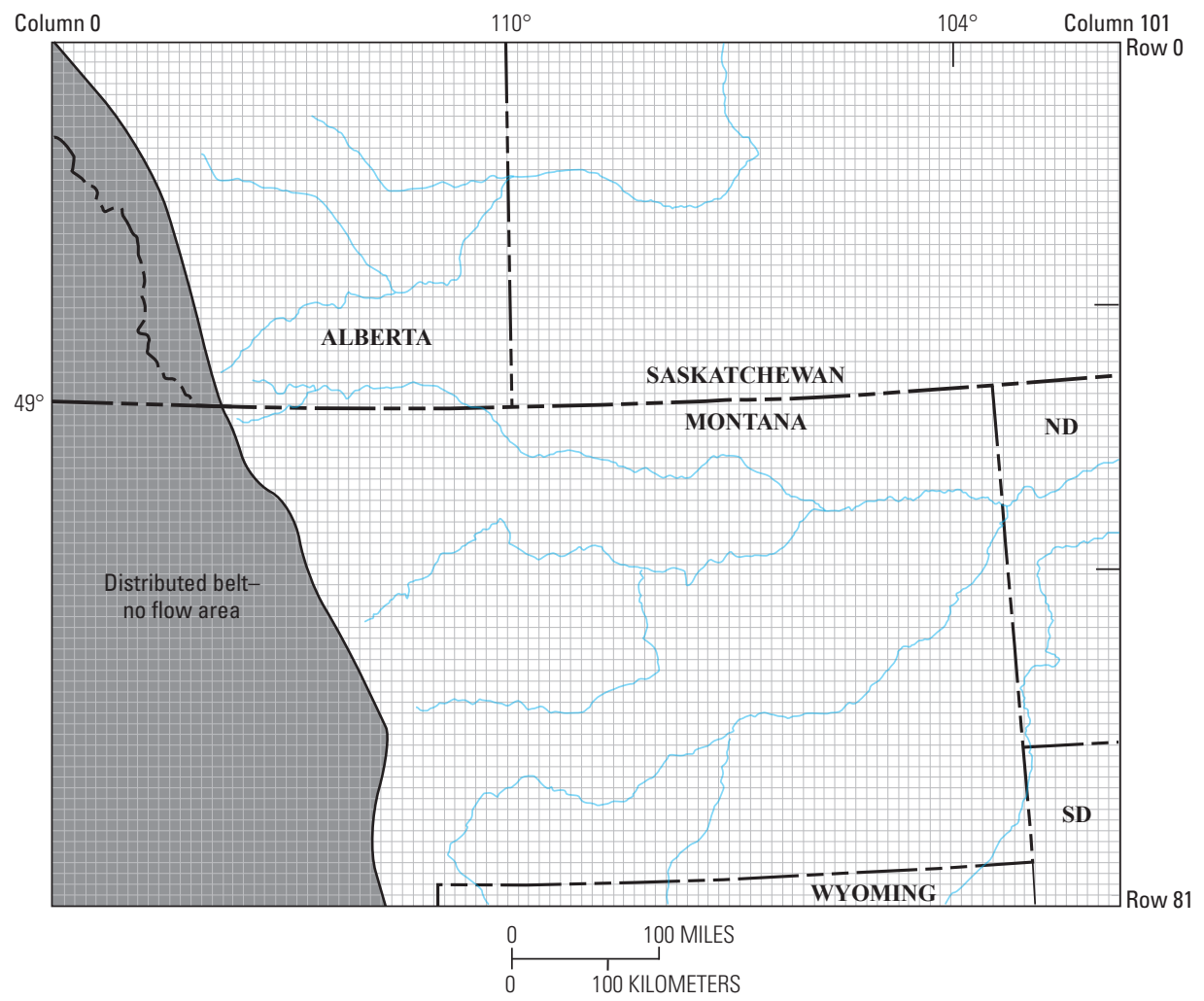

Figure 3. Map showing finite difference model grid. Individual cells are 6 mi per side.

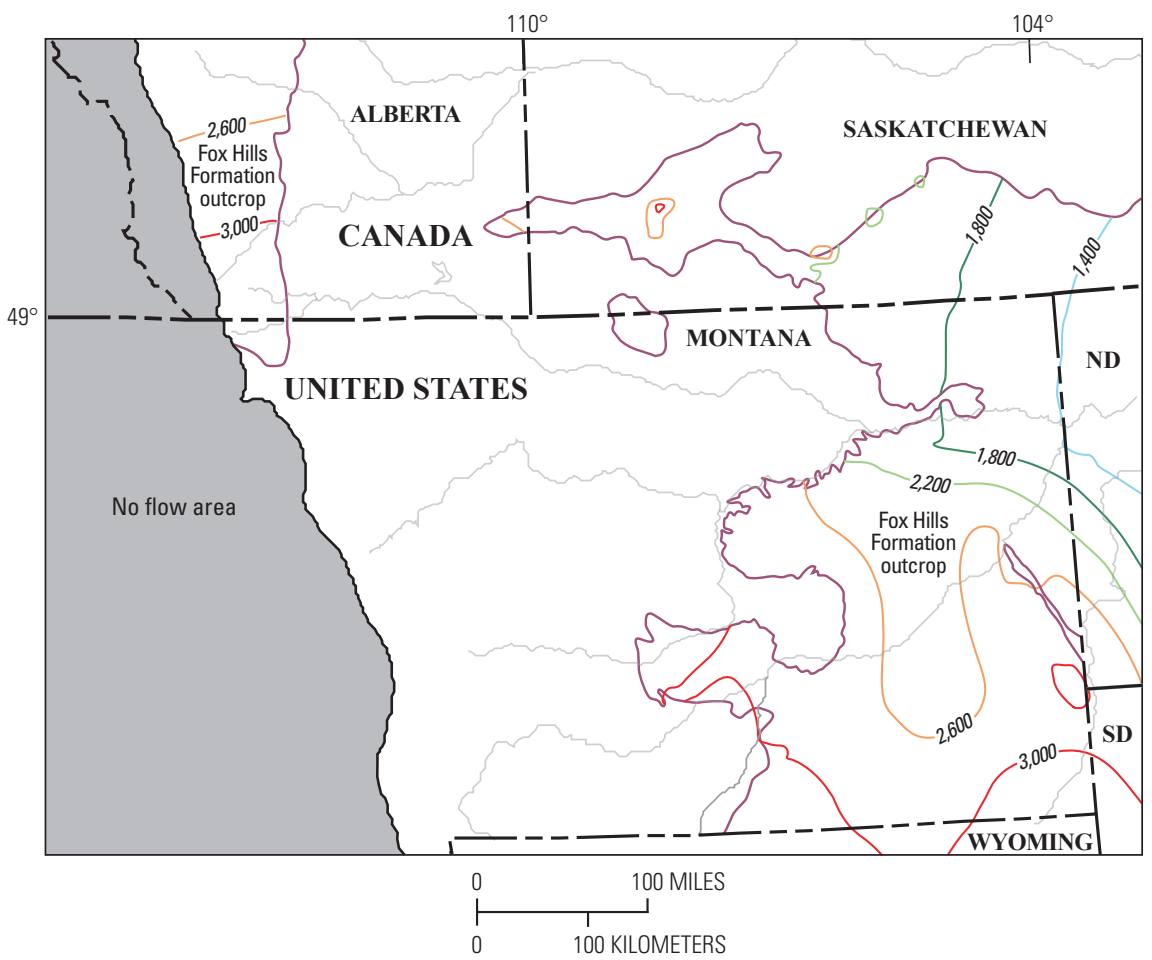

Figure 4. Map showing simulated head contours for the Fox Hills aquifer. Contours are in feet. Purple line is the basal contact of the Fox Hills Formation. 


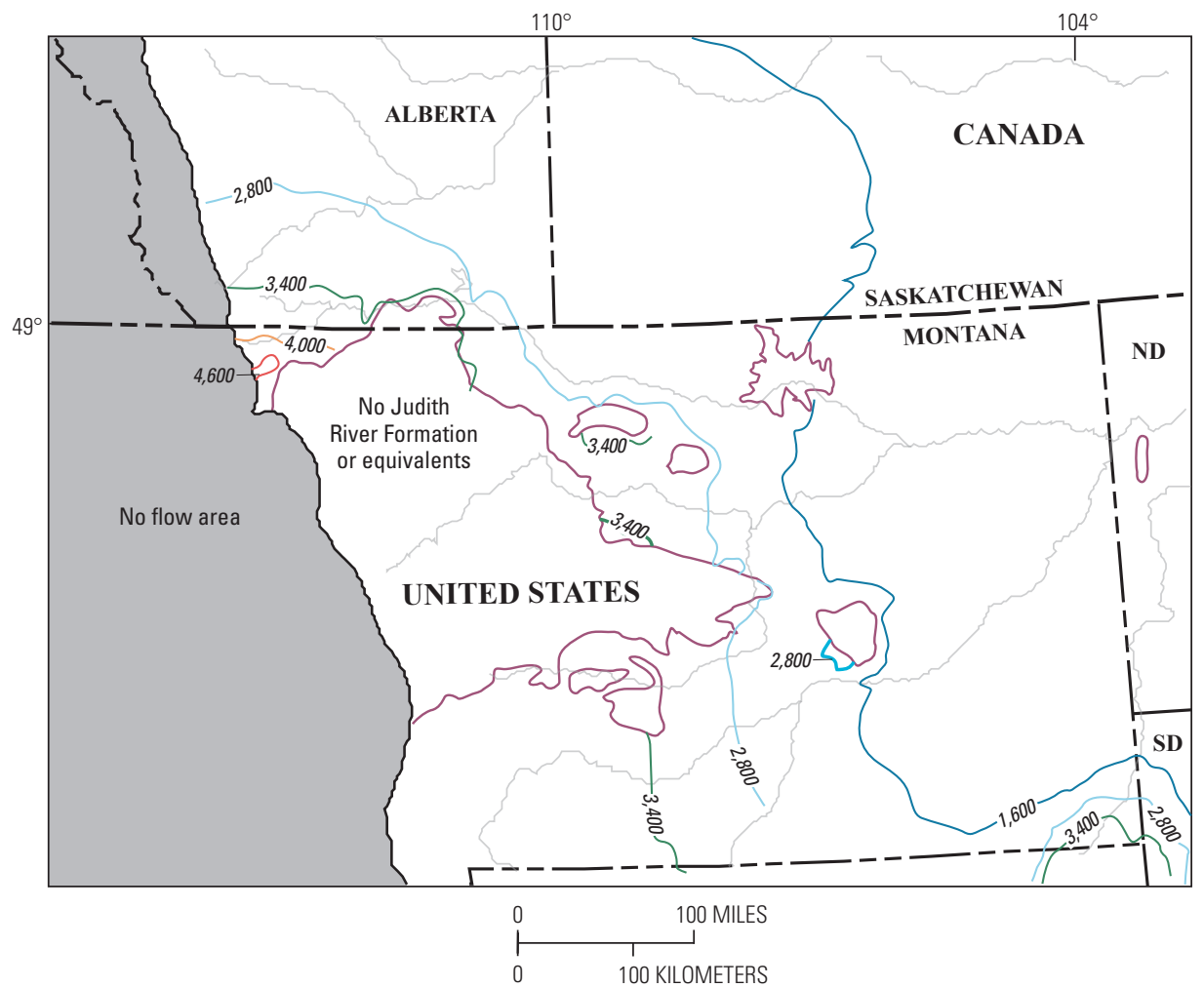

Figure 5. Map showing simulated head contours for the Judith River aquifer. Values are in feet. Purple line is the basal contact of the Judith River Formation.

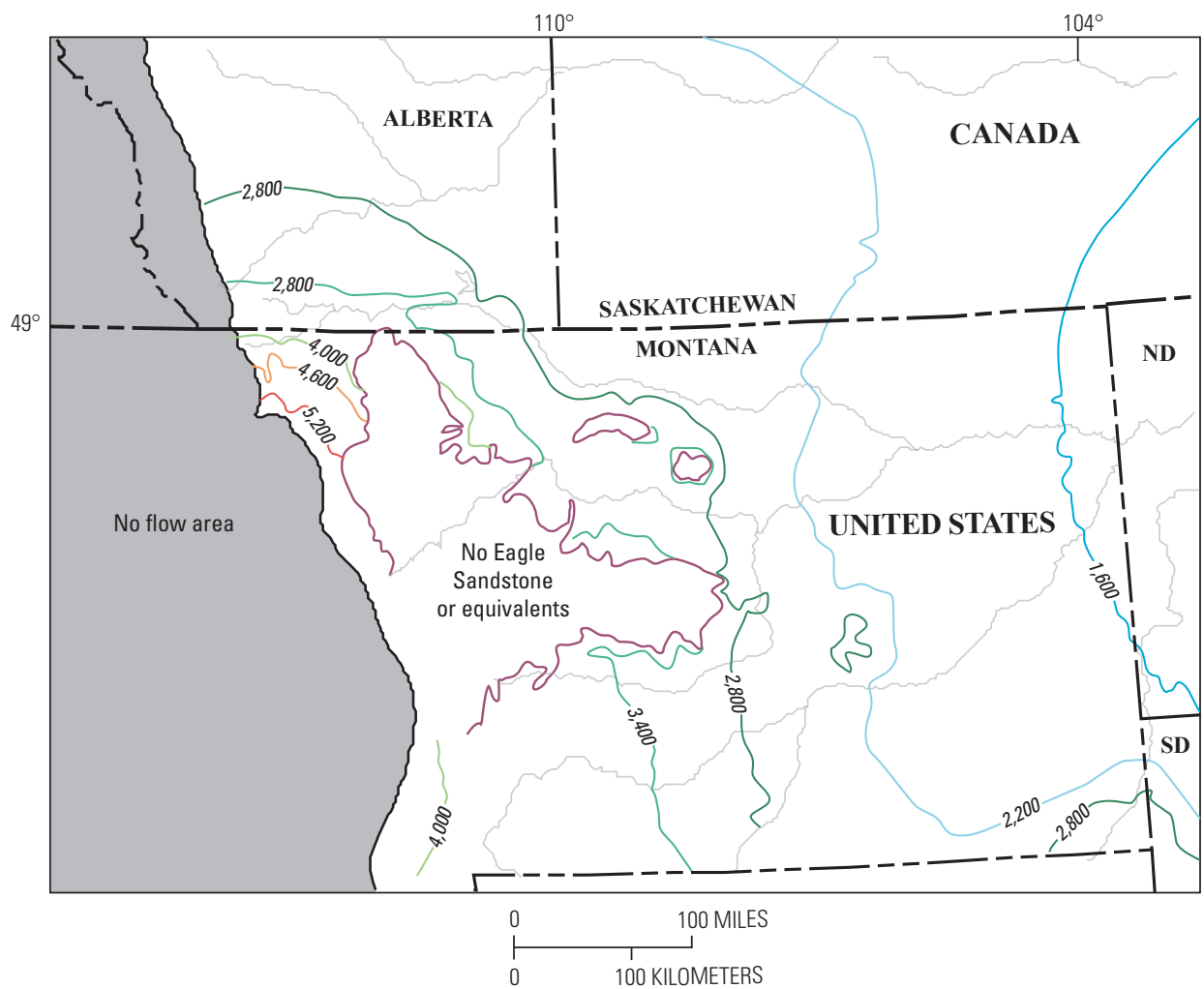

Figure 6. Map showing simulated head contours for the Eagle aquifer. Values are in feet. Purple lines are the basal contact of the Eagle Sandstone. 


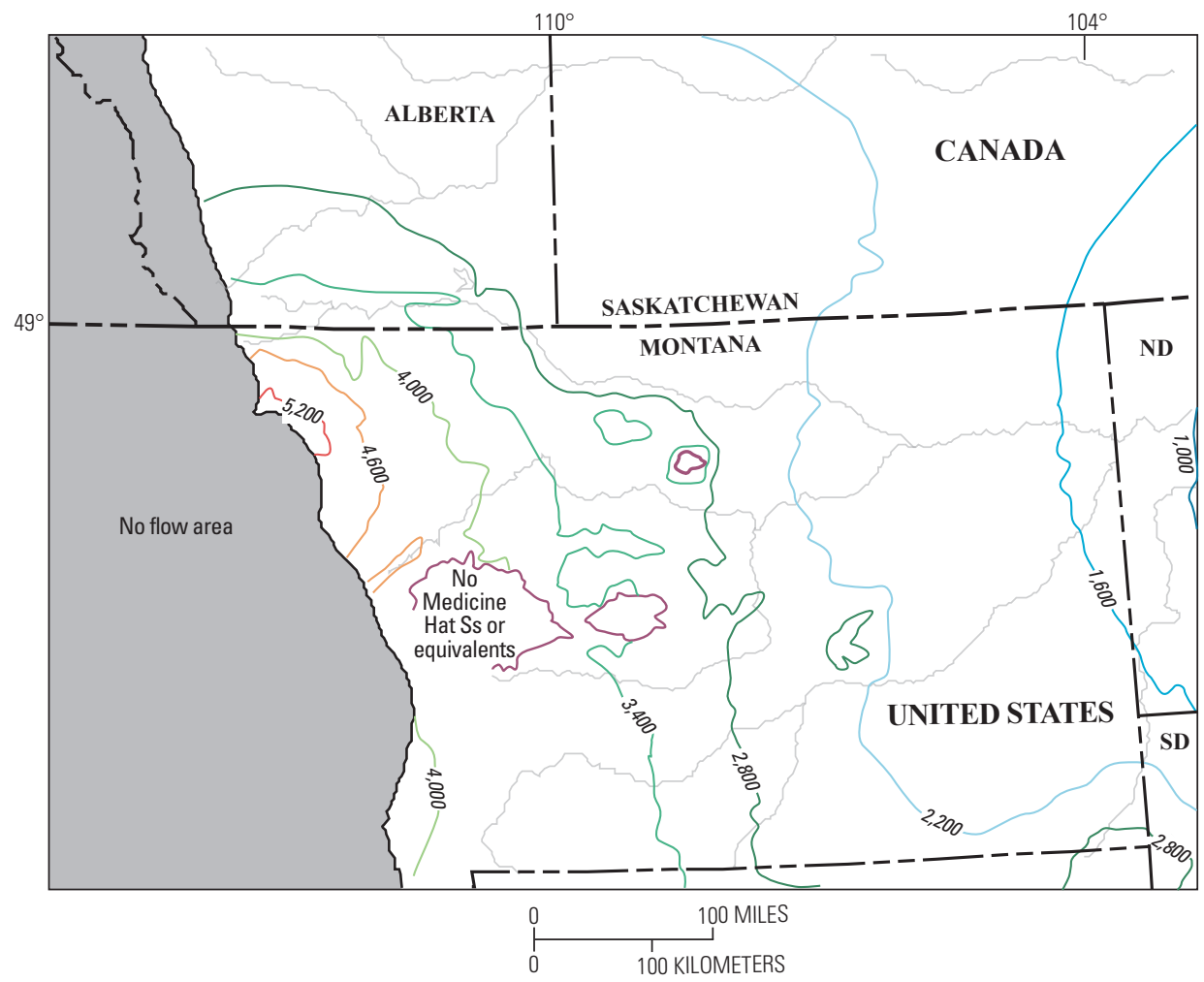

Figure 7. Map showing simulated head contours for the Medicine Hat aquifer. Values are in feet. Purple line is basal contact of the Medicine Hat Sandstone and equivalents.

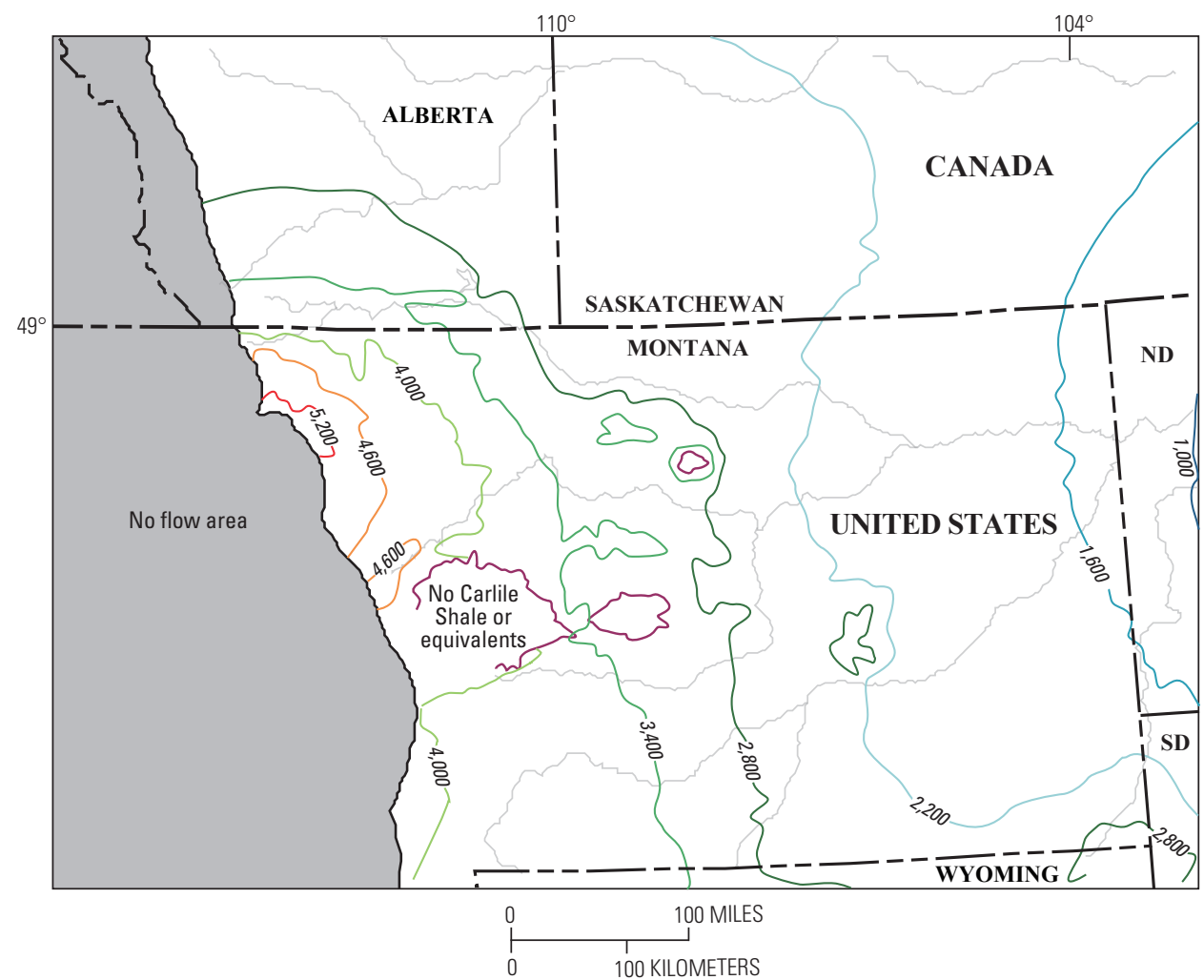

Figure 8. Map showing simulated head contours for the Bowdoin aquifer. Values are in feet. Purple line is basal contact of the Carlile Shale and equivalents. 


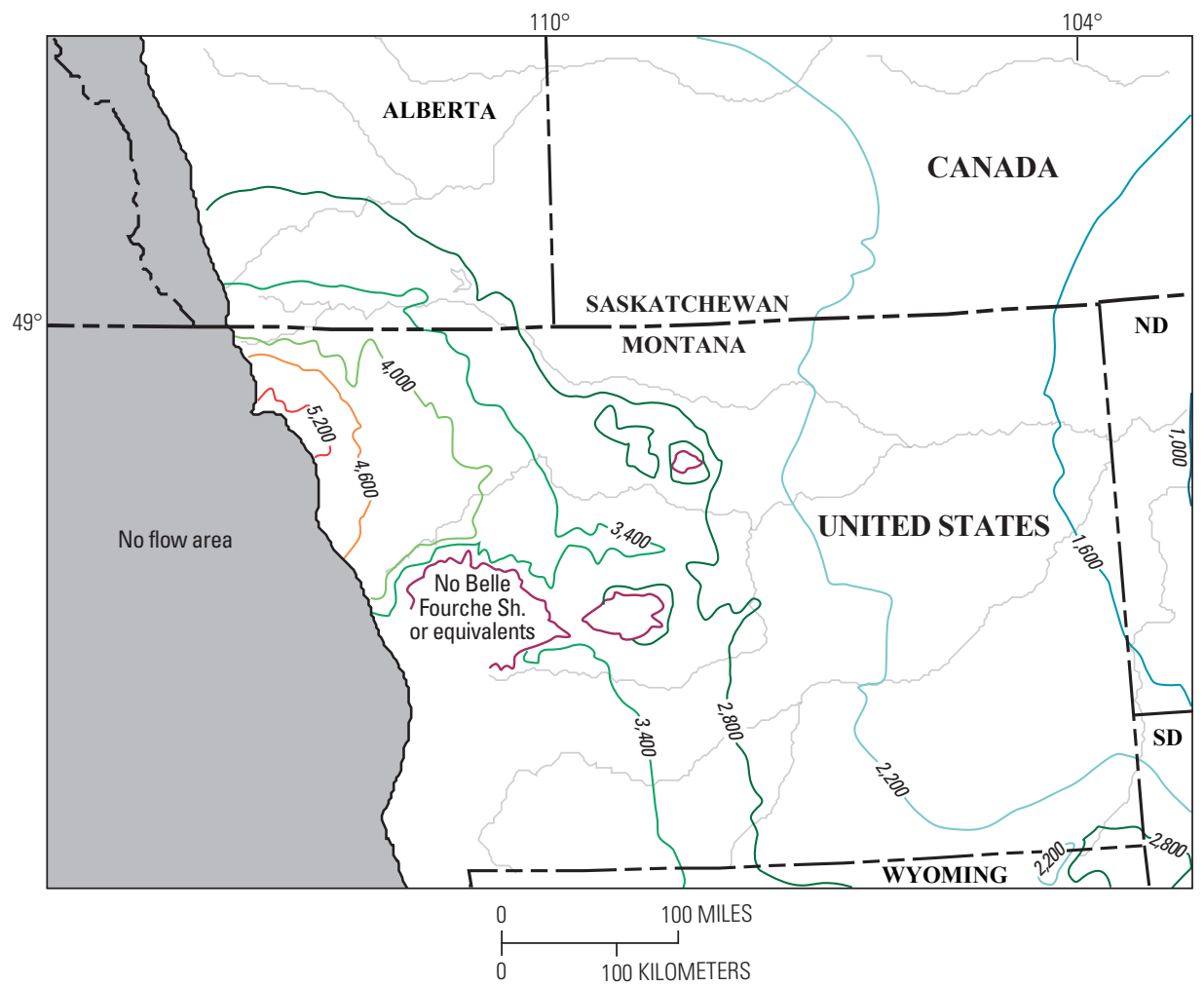

Figure 9. Map showing simulated head contours for the Second White Speckled aquifer. Values are in feet. Purple line is basal contact of the Belle Fourche Shale and equivalents.

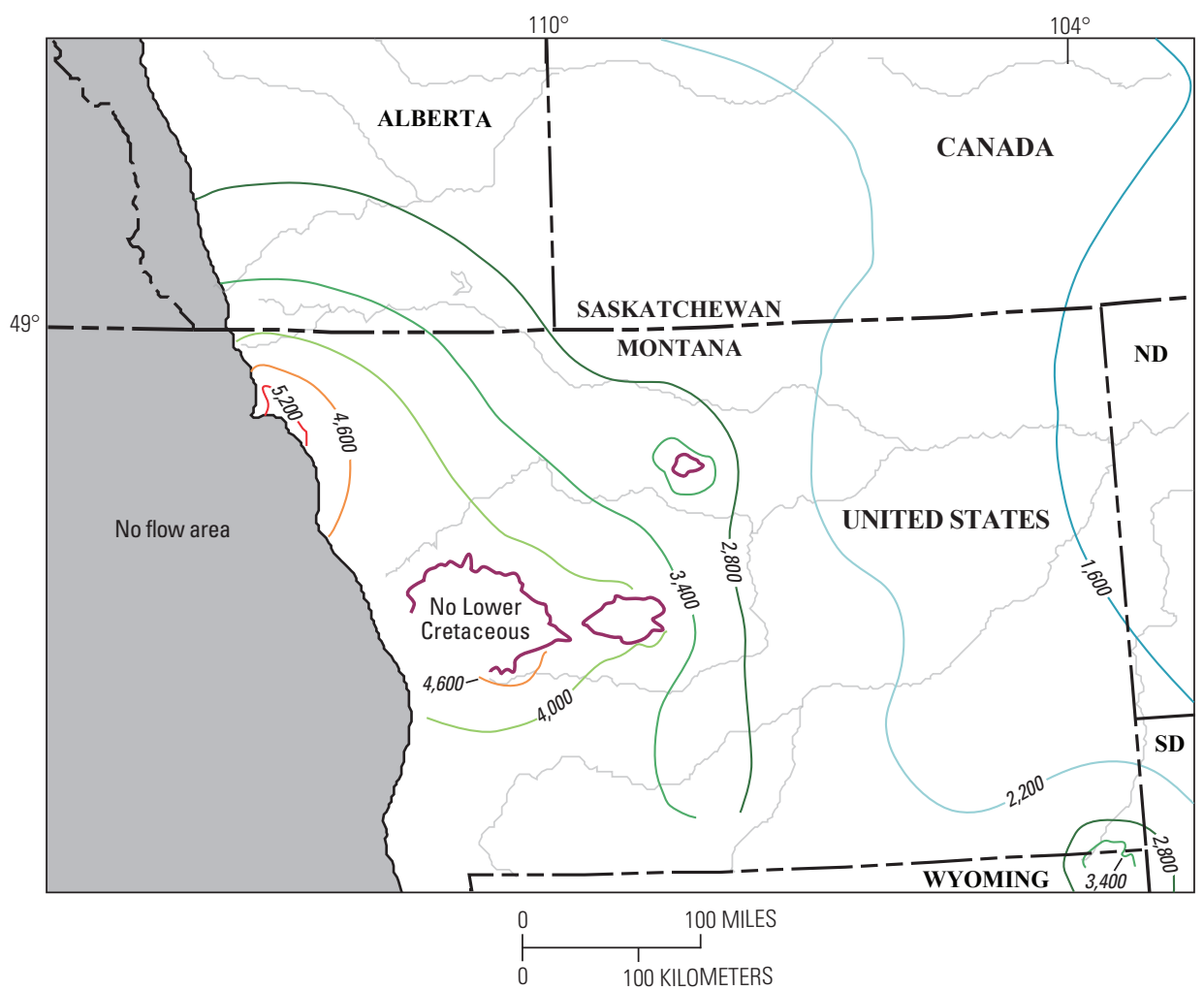

Figure 10. Map showing simulated head contours for the Lower Cretaceous aquifer. Values are in feet. Purple line is basal contact of the Lower Cretaceous units. 
Table 2. Drill-stem-test derived transmissivity of selected Cretaceous formations in Montana.

[Data and stratigraphic names from Levings, $1981 \mathrm{~b} ; \mathrm{Mbr}$, member; $\mathrm{ft}^{2} / \mathrm{d}$, feet squared per day; transmissivity $=$ permeability (hydraulic conductivity $\times$ thickness]

\begin{tabular}{lccc}
\hline & \multicolumn{2}{c}{ Transmissivity, } \\
Stratigraphic unit & Mean & $\begin{array}{c}\text { Geometric } \\
\text { mean }\end{array}$ & $\begin{array}{c}\text { Number } \\
\text { of tests }\end{array}$ \\
\cline { 2 - 3 } & 6.5 & 2.8 & 5 \\
\hline Judith River Formation & 1.5 & 1.2 & 21 \\
Greenhorn Limestone & 3.0 & 1.4 & 27 \\
Eagle Sandstone & 1.0 & 1.0 & 4 \\
Niobrara Formation & 1.0 & 1.0 & 1 \\
Mowry Shale & 3.0 & 1.3 & 23 \\
Mosby Sandstone Mbr. & 14.2 & 2.2 & 42 \\
Muddy Sandstone Mbr. & 11.3 & 3.1 & 12 \\
Dakota Sandstone & & & \\
\hline
\end{tabular}

Vertical permeability for aquifer layers was implicitly determined as one-tenth horizontal permeability. This determination was based on data from similar Cretaceous age sandstones from the Rocky Mountain area. For confining layers, vertical permeability was equal to the horizontal permeability.

\section{Hydraulic Head}

Potentiometric head varies considerably in the NGP and is controlled primarily by the elevation of recharge and discharge sites. Other factors, such as osmosis and chemical gradients, that could affect head were not included as part of this study. Recharge elevations at outcrop and subcrop sites in the west and southwest are much higher than discharge elevations at outcrop and subcrop sites to the east and northeast. Therefore, heads for all layers range from high values in the west and southwest to low values in the east and northeast, although there are local variations. Lobmeyer (1980) mapped head data for parts of the NGP, but he indicated that potentiometric head calculations contain inaccuracies as much as one-half to one contour interval (contour interval was 1,000 ft; $305 \mathrm{~m}$ ).

\section{Calibration}

Numerical simulation used the forward approach as designed in the flow code MODFLOW96 (Harbaugh and McDonald, 1996). Heads and discharge rates calculated from the simulation were considered calibrated when the simulated heads and discharge matched measured heads and discharge to accepted criteria. For this study the criteria is a visual match for the head contours. A trial-and-error method altered input parameters until a visual match was achieved, although altered parameters were always geologically reasonable, such as the model calibrated to head data described in Hitchon (1984) (fig. 18). Hitchon's figure is a line graph of distance, along a line of section, versus hydraulic head for the Milk River Formation. A simulated plot of the Milk River for a similar line of section (fig. 18) shows comparable head values at approximately the same geographic points.

Layer 13 (Lower Cretaceous aquifer, fig. 2) did not calibrate to a published potentiometric surface map (Lobmeyer, 1980). The simulated layer appears to be underpressured (lower heads) possibly because permeability of the strata is laterally consistent creating a high-velocity flow system. Model simulations using permeability sensitivity, however, failed to replicate the published map. The best results occurred when the confining layer above the Lower Cretaceous was given an unrealistically high vertical permeability allowing a large amount of water to leak from the Lower Cretaceous aquifer through the confining layer into the overlying aquifer. The leakage lowered hydraulic heads in the Lower Cretaceous, closely resembling measured heads. That method, however, resulted in the aquifer above the confining unit (Second White Speckled aquifer) with unrealistically high heads. Therefore, the Lower Cretaceous layer was modeled using the initial permeability, although the Lower Cretaceous layer did not calibrate to published head. However, other Upper Cretaceous layers calibrated to available data. If the Lower Cretaceous is compartmentalized from permeability

Table 3. Permeability values cited in the literature and used to help constrain model input.

[Northern and southern refer to areas within the study area; ft/d, feet per day; Fm., Formation. Permeability and hydraulic conductivity are used interchangeably. To convert $\mathrm{ft} / \mathrm{d}$ to millidarcy multiply by 364.0 ]

\begin{tabular}{|c|c|c|c|c|c|}
\hline Rock type & Method & $\begin{array}{c}\text { Permeability } \\
\mathrm{ft} / \mathrm{d}\end{array}$ & $\begin{array}{c}\text { Formation, } \\
\text { interval, or basin }\end{array}$ & Comment & Reference \\
\hline Sandstone & Calculated & $.003-.27$ & Milk River Fm. & Northern area & Berkenpas (1991) \\
\hline Sandstone & Field & $6.0 \mathrm{E}-05-27.4$ & Lower Cretaceous & Denver Basin & Belitz and Bredehoedft (1988) \\
\hline Sandstone & Simulated & $.001-23.0$ & Lower Cretaceous & Denver Basin & Belitz and Bredehoedft (1988) \\
\hline Sandstone & Simulated & $20-130$ & Lower Cretaceous & North Dakota & Butler (1984) \\
\hline Shale & Simulated & $2.74 \mathrm{E}-06$ & Pierre Shale & Deep depth & $\begin{array}{l}\text { Neuzil and Bredehoedft (1981) } \\
\text { Neuzil and others (1984) }\end{array}$ \\
\hline Shale & Simulated & 8.64E-08 & Denver Basin & & Belitz and Bredehoedft (1988) \\
\hline Shale & Simulated & $8.34 \mathrm{E}-08$ & Upper Cretaceous & Average value & Corbet and Bethke (1992) \\
\hline Shale & Simulated & $8.34 \mathrm{E}-10$ & Upper Cretaceous & Compressibility used & Corbet and Bethke (1992) \\
\hline
\end{tabular}




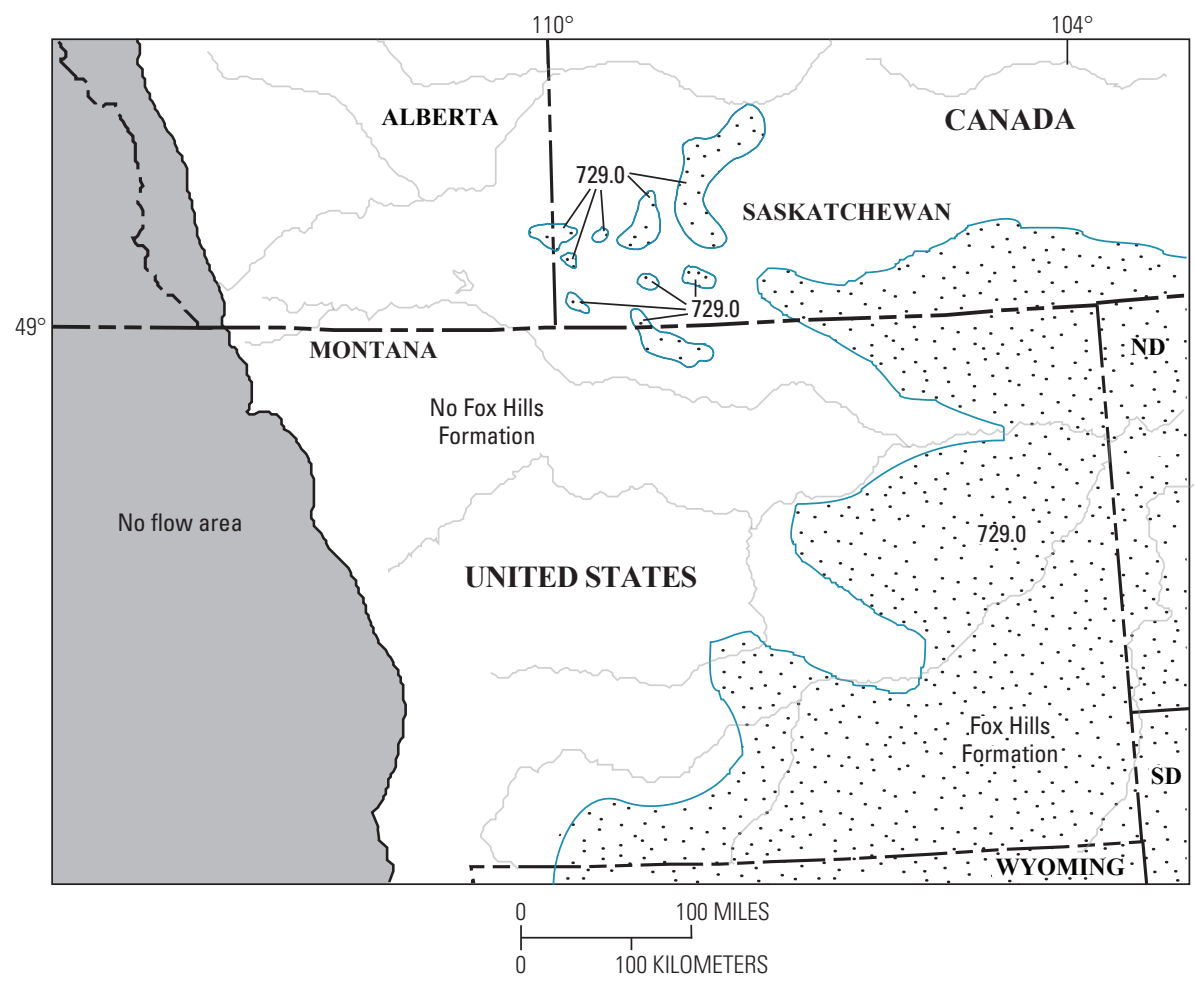

Figure 11. Map of Fox Hills aquifer showing generalized depositional environments. Values are permeability (in millidarcies) used in model.

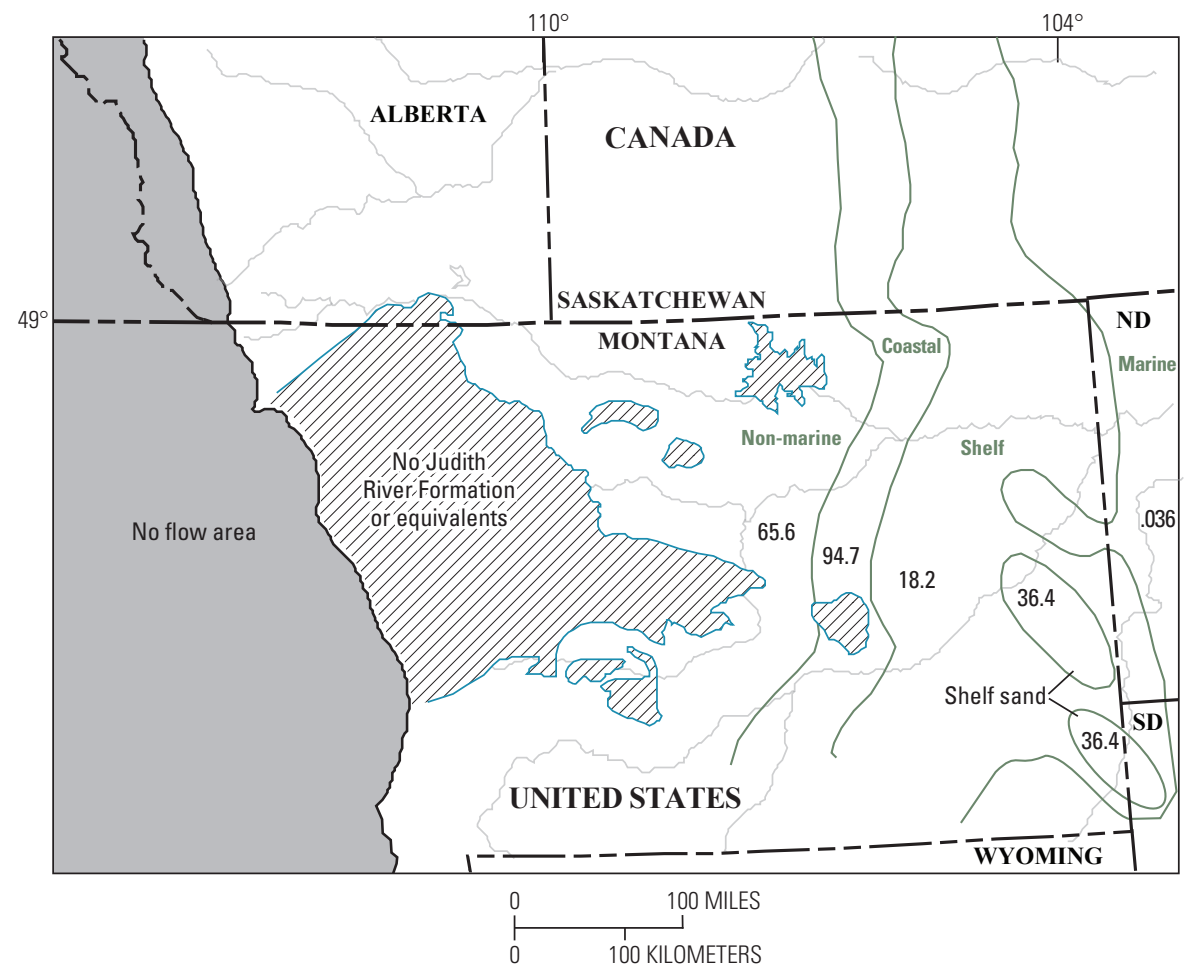

Figure 12. Map of Judith River aquifer showing generalized depositional environments. Numbers are permeability values (in millidarcies) used in model. Diagonal ruled areas are Judith River Formation outcrop. 


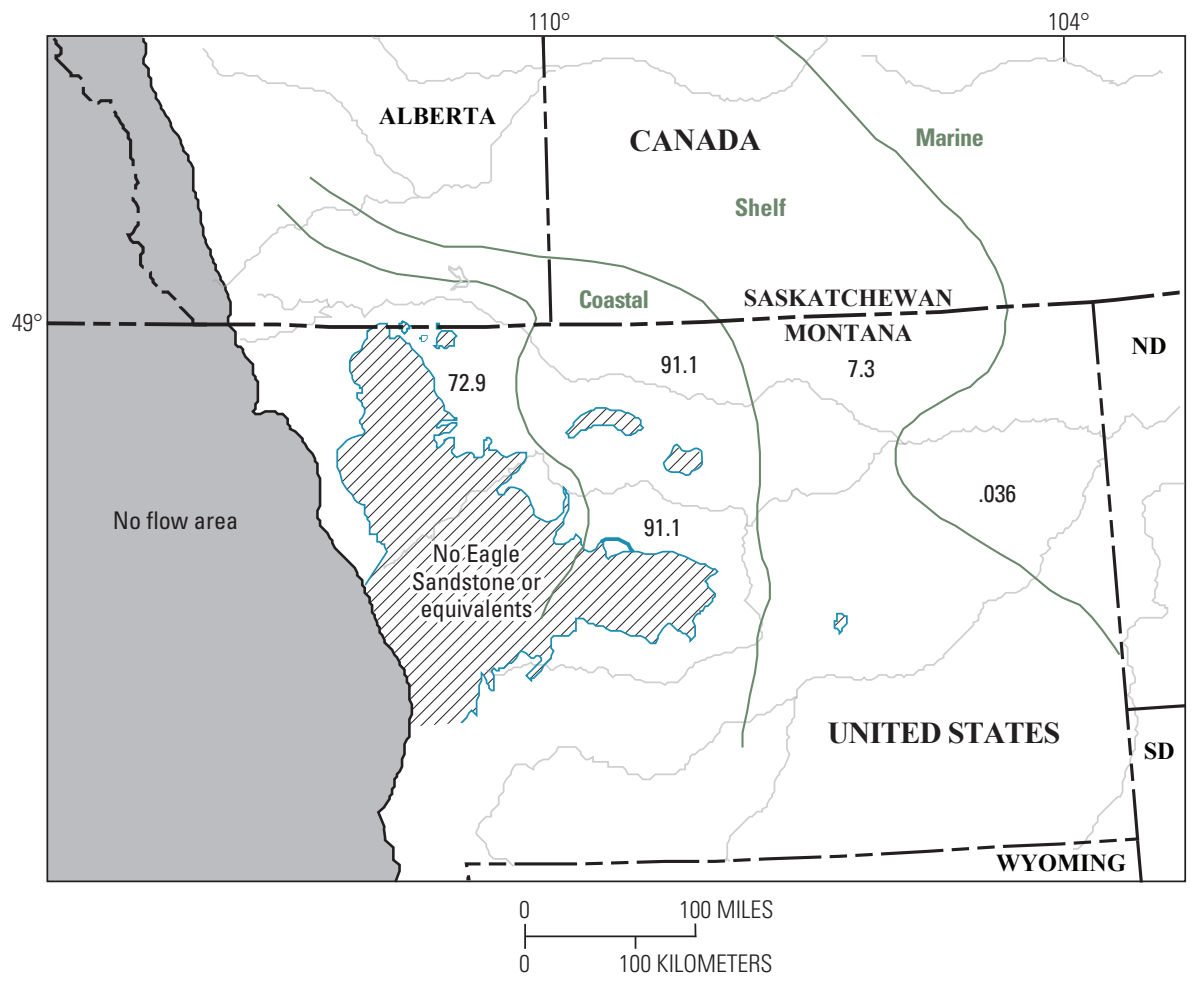

Figure 13. Map of Eagle aquifer showing generalized depositional environments. Numbers are permeability values (in millidarcies) used in model. Diagonal ruled areas are Eagle Sandstone outcrop.

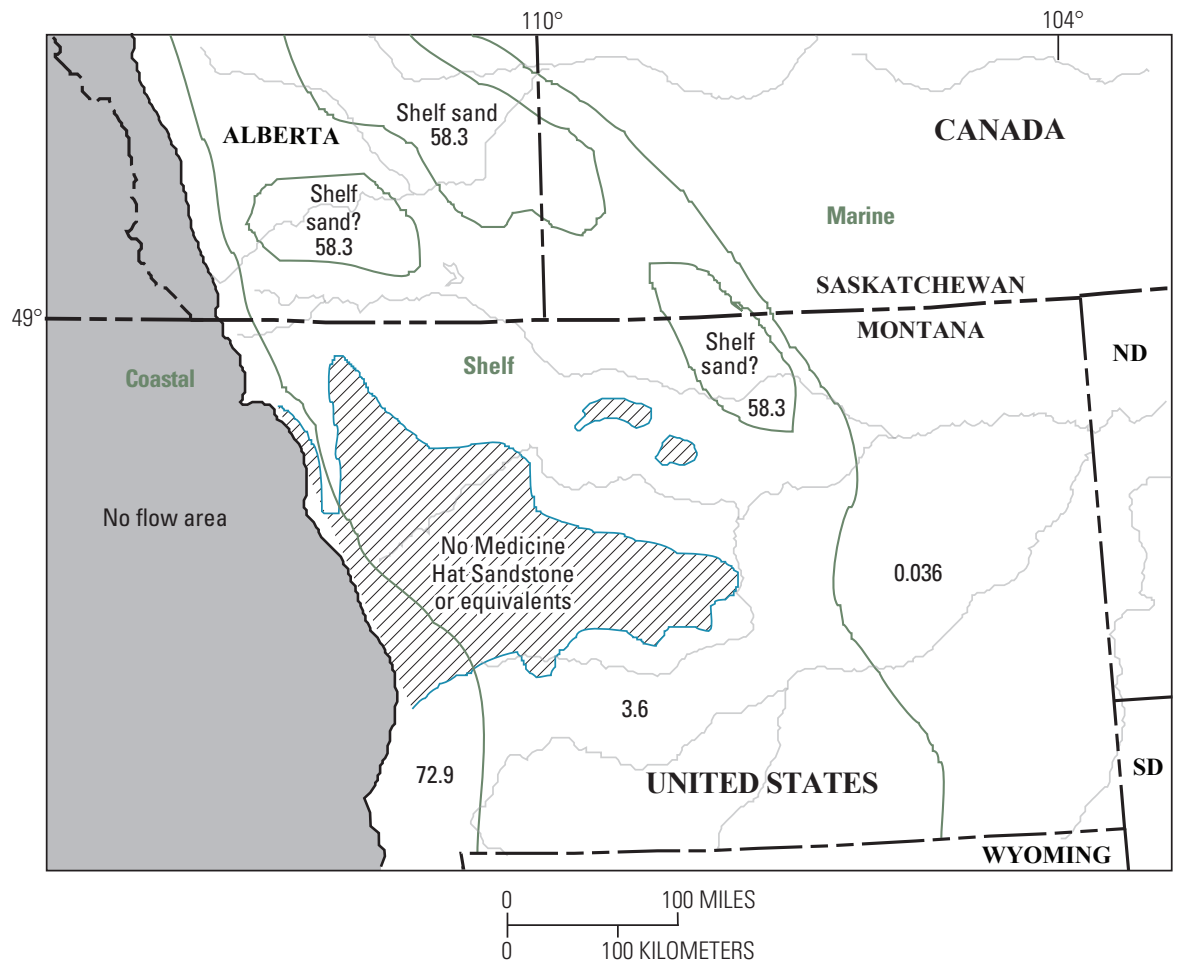

Figure 14. Map of Medicine Hat aquifer showing generalized depositional environments. Numbers are permeability values (in millidarcies) used in model. Diagonal ruled areas are Medicine Hat Sandstone outcrop. 


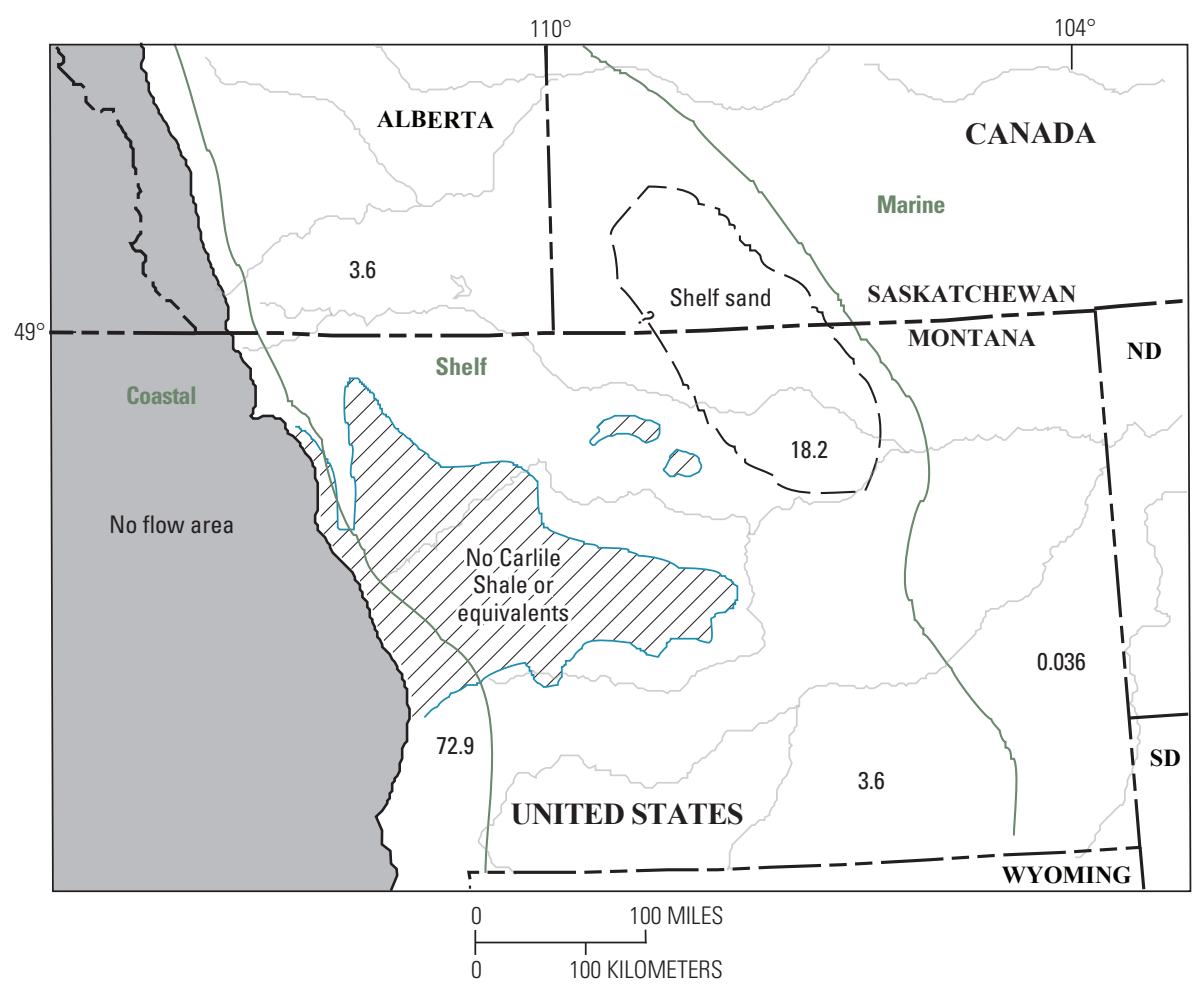

Figure 15. Map of Bowdoin aquifer showing generalized depositional environments. Numbers are permeability values (in millidarcies) used in model. Diagonal ruled areas are Carlile Shale/Bowdoin Sandstone outcrop.

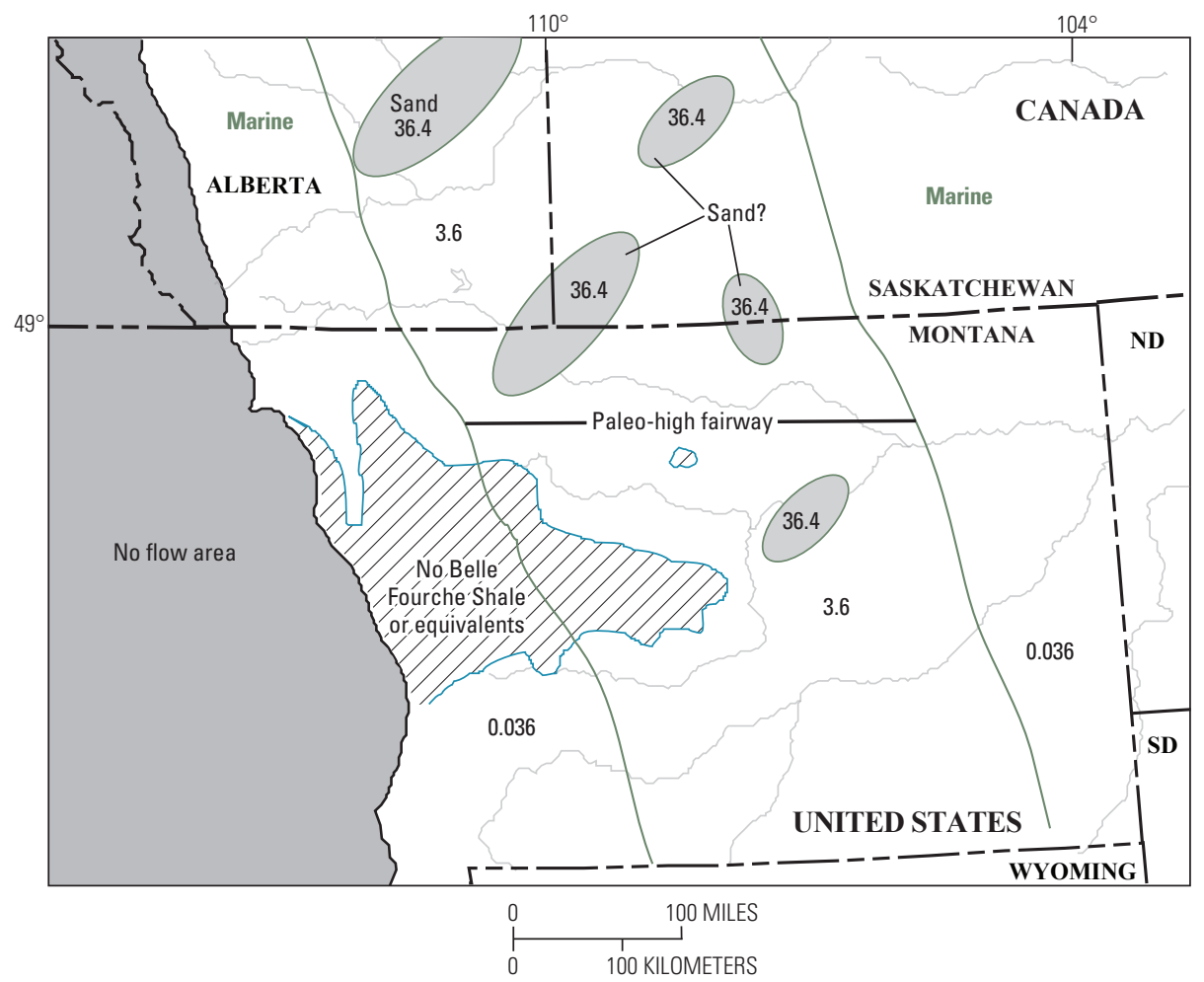

Figure 16. Map of Second White Speckled aquifer showing generalized depositional environments. Numbers are permeabilities (in millidarcies) used in model. Diagonal ruled areas are Belle Fourche Shale/Second White Speckled sandstone outcrop. 


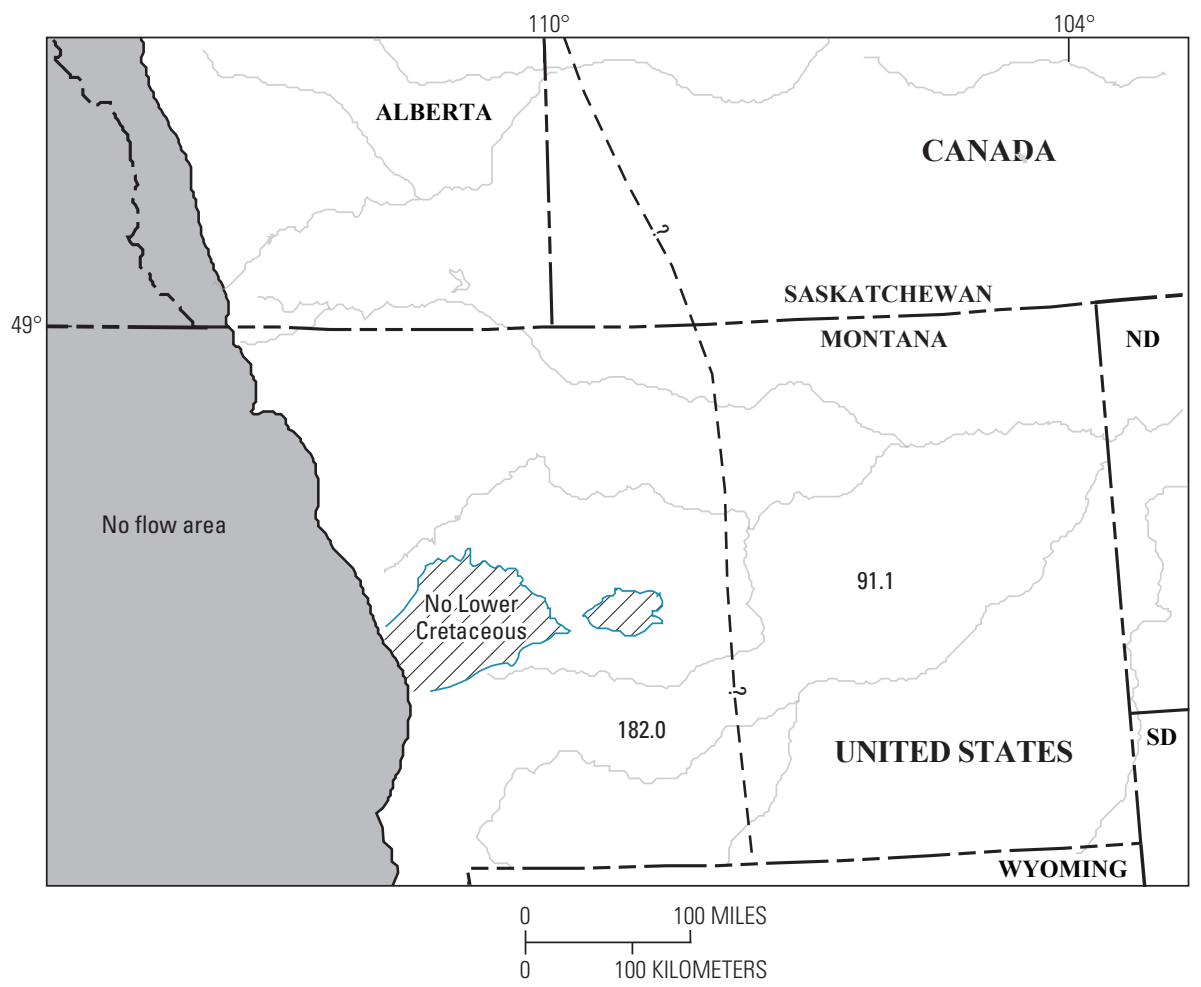

Figure 17. Map of Lower Cretaceous aquifer showing generalized depositional environments. Numbers are permeability values (in millidarcies) used in model. Diagonal ruled areas are Lower Cretaceous outcrop.

heterogeneity, then the overlying units should be hydraulically segregated from the Lower Cretaceous, implying little vertical leakage. In the northeast corner of Montana, however, there may be minor vertical leakage because the upper layers seem to be influenced by Lower Cretaceous heads. If true, the leakage may help redistribute gas to the stratigraphically highest porosity and permeability layers.

\section{Model Results}

Model results were used as a general indicator of flow direction, volume, and velocity, not to explicitly define values or rates at specific points. Modeling results were intended to help explain present-day geochemical trends and anomalies associated with groundwater flow, and help conceptualize biogenic gas accumulations in low-permeability reservoirs. Although gas generated in place is by methanogenesis processes, groundwater can help distribute and trap gas. The physical process of water and biogenic gas migration at shallow depths is not clear, but probably the gas is dissolved in water in the early stages of generation. Pressure reduction from uplift and erosion can exolve gas to form a two-phase flow system. In rock of low permeability, water may displace gas depending on hydraulic gradients.
All model simulations were run to steady state, and head was regionally controlled by constant head boundaries for all active model layers. In addition, head in the upper layer was influenced using precipitation recharge. Head gradients over the model area for the bottom five layers vary slightly, but the upper two layers have gradients that vary greatly due to extensive outcrop exposure. Most of the head gradients are steeper near outcrops to the west and southwest than to the east and northeast. Hydraulic head maps for each aquifer layer are shown in figures 4-10.

Simulated heads for the Lower Cretaceous aquifer (layer 13, fig. 10) are relatively smooth and mimic the small permeability contrast distributions and small thickness variation. The average hydraulic gradient was $10.0 \mathrm{ft} / \mathrm{mi}(2.3 \mathrm{~m} / \mathrm{km})$ although the gradient was steeper on the west side than on the east. Simulations by Downey (1986) for parts of the Lower Cretaceous aquifer had similar gradients for Montana. Overlying aquifer layers show more head contour tortuosity due to permeability variability and the relatively low permeability values of shallow and deep shelf sandstones. Some of the layers show closed or nearly closed contours indicating local groundwater sources or sinks.

Hydraulic gradients for the Medicine Hat, Bowdoin, and Second White Speckled aquifers, layers 7, 9, and 11 (figs. 7-9) respectively, are similar with $11.2 \mathrm{ft} / \mathrm{mi}(2.1 \mathrm{~m} / \mathrm{km})$ on the west side and $5.0 \mathrm{ft} / \mathrm{mi}(0.95 \mathrm{~m} / \mathrm{km})$ on the east side. 

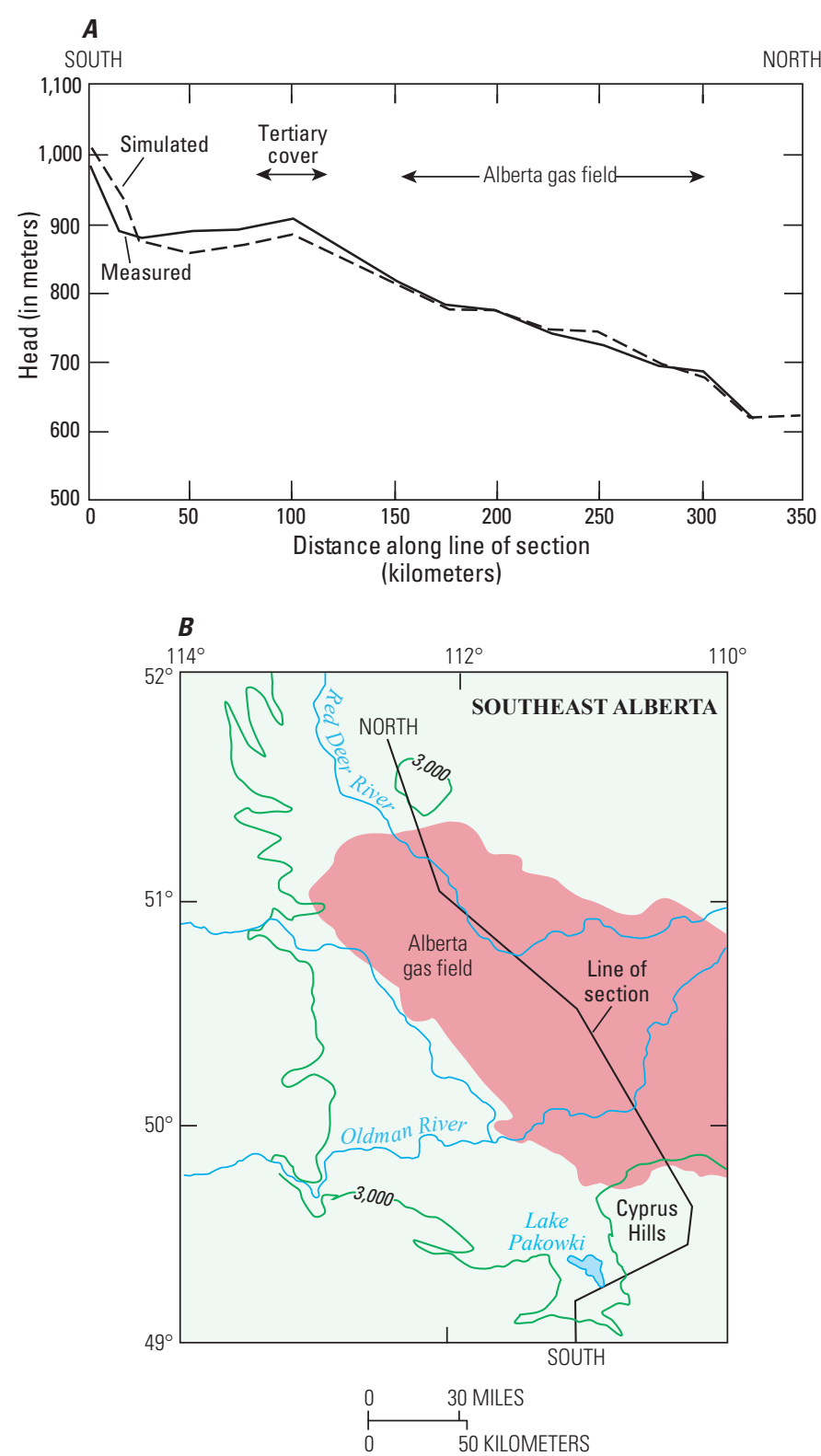

Figure 18. A. Graph of simulated and measured hydraulic head profiles from the Milk River aquifer in southeast Alberta, Canada. B. Map showing the line of section for calibration profile of $A$; zero distance is south. Measured data and location map are from Hitchon (1984).

Hydraulic gradients for the Fox Hills, Judith River, and Eagle aquifers, layers 1, 3, and 5 (figs. 4-6) respectively, are $5.9 \mathrm{ft} / \mathrm{mi}(1.1 \mathrm{~m} / \mathrm{km})$ and are generally constant over the study area, although the Eagle has a steep, north-trending gradient on the extreme west side.

Regional velocity, or flux, can be calculated where flux is equal to permeability times gradient. The concept of flux is macroscopic in scale and is independent of rock properties such as porosity. Darcy (specific discharge) flux is defined as permeability times gradient divided by rock porosity, which accounts for the tortuosity of a flow path. Table 4 shows that the Darcy velocity (flux) for all model layers ranges from a low of $9.29 \mathrm{E}-08 \mathrm{ft} / \mathrm{d}$ to the east (layer 11) to a high of $2.19 \mathrm{E}-03 \mathrm{ft} / \mathrm{d}$ to the east and west (layer 1).

Particle velocity was calculated by multiplying the mean permeability by the mean gradient divided by the mean effective porosity. This velocity is a function of the microscopic characteristics of the rock and represents an average effective velocity, similar to the velocity of a particle injected into the system. Table 4 shows that the velocities for all model layers range from a low of $6.0 \mathrm{E}-07 \mathrm{ft} / \mathrm{d}$ to the east (layer 11) to a high of $1.0 \mathrm{E}-02 \mathrm{ft} / \mathrm{d}$ to the east and west (layer 1 ).

\section{Discussion}

The distribution of biogenic gas in continuous reservoirs is a result of several geologic and hydraulic factors, including groundwater, which plays two important roles: (1) provides up-gradient hydraulic head on down-gradient low-permeability reservoirs to counter the buoyancy forces of gas (fig. 19), and (2) redistributes gas beneath Tertiary capped topographic remnants to adjacent topographic lows.

Assuming that biogenic gas generation occurred early in the burial history of Upper Cretaceous rocks of the NGP (Rice and Claypool, 1981; Fishman and others, 2001), minor amounts of biogenic gas were generated during maximum burial (in the Miocene) because deep burial and stagnant groundwater movement limited recharge and new bacteria accumulation. Early gas generation was trapped by capillary forces in low-pressure and low-permeability rock. Most of the existing biogenic gas was generated before maximum burial, although some biogenic gas may have generated at maximum burial and may be generating today. Therefore, prior to Laramide orogeny, the relatively flat-lying Upper Cretaceous units were probably generating and storing biogenic gas. During and post-Laramide time, formations such as the Eagle Sandstone and the Milk River Formation were structurally tilted with high-permeability rock up-structural dip. The distribution of gas, therefore, is either a result of the updip gas being flushed from the system, or the updip gas was redistributed down gradient into low-permeability rock. Gas that was generated in low-permeability rock and the redistributed gas were trapped because hydraulic gradients plus capillary forces are greater than buoyancy forces. It is unclear if the gas migrates as a single phase (being dissolved in groundwater), or separately as a two-phase system. In a single-phase system, the gas and water migrate at the same rate and extent, and the gas is later exolved as the formation pressure is lowered. In a two-phase system, migration pathways of the gas are more difficult to predict because there are more forces acting on the gas as well as the hydrodynamics of the water system.

Modeled head distributions are shown in three cross sections (fig. 20). One line of section crosses the Alberta gas field, another crosses Tertiary outcrops, and the third crosses the Bowdoin gas 
field and Tertiary outcrops. The purpose of the cross sections was to determine the spatial relation between vertical and horizontal head gradients of Tertiary remnants and gas fields.

Although not conclusive, the two-dimensional sections show that for areas not covered by Tertiary strata, the gradient is generally uniform and flow is horizontal. However, the presence of Tertiary capped remnants creates a change in flow pattern due to high head gradients initiated in the upper parts of the remnant (Toth, 1963). Examples from figure 20 show the steep gradients that continue nearly vertical through the Eagle aquifer (layer 5) and into the Bowdoin aquifer (layer 9). As the thickness increases from the top of the remnant (at the water table) to the base of the remnant (topographic floor), the head gradient also increases.

The data suggest that the present distribution of biogenic gas is a function of the spatial distribution of Tertiary capped remnants and that head gradients were high under the remnants relative to adjacent topographic lows. The displacement of gas began in late Tertiary when the change in topography commenced. Areas where there were high head gradients displaced gas by hydraulic pressure overcoming capillary pressures. Gas was displaced under remnants because high head gradients were greater than the capillary pressure of the gas-filled rock. In turn, the gas was redistributed down and away from the remnants. As the lateral distance from the remnants increased, head gradients gradually declined, allowing the gas to exolve. Hitchon $(1984$, p. 742$)$ stated that there was a genetic link between topography and hydrodynamics and that areas of high topography are also areas of high head potential (fig. 21). According to Hitchon (1984), topographic relief controls near-surface flow patterns as well as regional flow patterns.

Sixteen capillary pressure curves for the Milk River Formation indicate a large range of entry level and R35 pore throat sizes and associated capillary pressures (table 5). Median initial entry or displacement pressures for the Milk River are $124 \mathrm{ft}$ of water and a median R35 displacement pressure of 2,368 ft of water. Assuming the thickness of the Tertiary remnant is approximately $2,500 \mathrm{ft}$, most of the displacement pressures from the capillary pressure curves indicate that the hydraulic pressure under Tertiary remnants is larger than the displacement pressures for entry level and R35 displacement pressures of the Milk River. This indicates that over half of the gas in the reservoir beneath remnants could be displaced. Therefore, as the Tertiary remnants formed, water could displace exolved gas to areas where the hydraulic and displacement pressures were equal. The volume of gas that was displaced is a function of original water saturation, effective porosity, and relative water and gas permeability. However, the data suggest that a large percentage of gas that originally resided in high-permeability zones could be displaced. According to Byrnes (1997), high-permeability sandstones in

Table 4. Average regional groundwater-flow velocity for model aquifer layers.

[West and east refer to directions within the study area; $\mathrm{ft} / \mathrm{d}$, feet per day; $\mathrm{ft} / \mathrm{ft}$, feet per feet; $\mathrm{ft}^{2}$, feet squared; $\mathrm{ft}^{3} / \mathrm{s}$, cubic feet per second; to calculate area, vertical axis ranges from 20 to $100 \mathrm{ft}$; Darcy velocity is the average velocity along a transect; velocity is particle velocity. Permeability and hydraulic conductivity are interchangeable]

\begin{tabular}{|c|c|c|c|c|c|c|c|c|c|c|c|}
\hline \multirow[b]{2}{*}{$\begin{array}{l}\text { Model } \\
\text { layer }\end{array}$} & \multicolumn{4}{|c|}{ West } & \multicolumn{4}{|c|}{ East } & \multirow[b]{2}{*}{$\begin{array}{l}\text { Average } \\
\text { porosity }\end{array}$} & \multirow[b]{2}{*}{$\begin{array}{c}\text { Area } \\
\mathrm{ft}^{2}\end{array}$} & \multirow[b]{2}{*}{$\begin{array}{c}\text { Average } \\
\text { flow rate } \\
\mathrm{ft}^{3} / \mathrm{s}\end{array}$} \\
\hline & $\begin{array}{c}\text { Permeability } \\
\text { ft/d }\end{array}$ & $\begin{array}{c}\text { Gradient } \\
\mathrm{ft} / \mathrm{ft}\end{array}$ & $\begin{array}{c}\text { Darcy } \\
\text { velocity } \\
\text { ft/d }\end{array}$ & $\begin{array}{c}\text { Velocity } \\
\text { ft/d }\end{array}$ & $\begin{array}{c}\text { Permeability } \\
\mathrm{ft} / \mathrm{d}\end{array}$ & $\begin{array}{c}\text { Gradient } \\
\mathrm{ft} / \mathrm{ft}\end{array}$ & $\begin{array}{c}\text { Darcy } \\
\text { velocity } \\
\text { ft/d }\end{array}$ & $\begin{array}{c}\text { Velocity } \\
\text { ft/d }\end{array}$ & & & \\
\hline 3 & 0.26 & $1.10 \mathrm{E}-03$ & $2.85 \mathrm{E}-04$ & $1.56 \mathrm{E}-03$ & 0.026 & $1.10 \mathrm{E}-03$ & $2.85 \mathrm{E}-05$ & $1.56 \mathrm{E}-04$ & 0.183 & $98,400,000$ & 0.24 \\
\hline 5 & 0.25 & $1.10 \mathrm{E}-03$ & $2.74 \mathrm{E}-04$ & $2.11 \mathrm{E}-03$ & 0.025 & $1.10 \mathrm{E}-03$ & 2.74E-05 & $2.11 \mathrm{E}-04$ & 0.130 & $98,400,000$ & 0.25 \\
\hline 7 & 0.20 & $2.04 \mathrm{E}-03$ & 4.09E-04 & $2.35 \mathrm{E}-03$ & 0.020 & $9.11 \mathrm{E}-04$ & $1.82 \mathrm{E}-05$ & $1.05 \mathrm{E}-04$ & 0.174 & $39,300,000$ & 0.08 \\
\hline 13 & 0.50 & $2.08 \mathrm{E}-03$ & $1.04 \mathrm{E}-03$ & $5.69 \mathrm{E}-03$ & 0.250 & $9.29 \mathrm{E}-04$ & $2.32 \mathrm{E}-04$ & $1.27 \mathrm{E}-03$ & 0.183 & $196,800,000$ & 1.0 \\
\hline
\end{tabular}

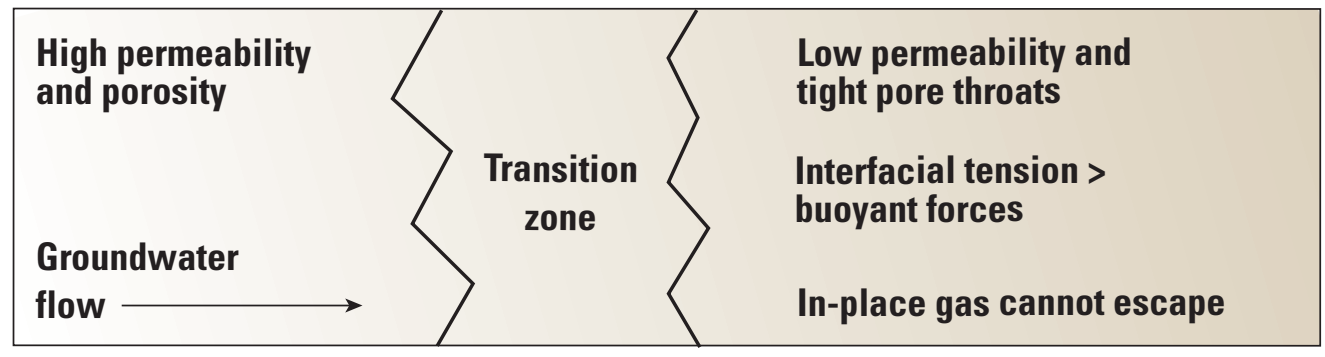

Figure 19. Diagram showing a conceptual model of a gas trapping mechanism for the Milk River Formation and Medicine Hat Sandstone. Concept is developed from Masters (1979). 

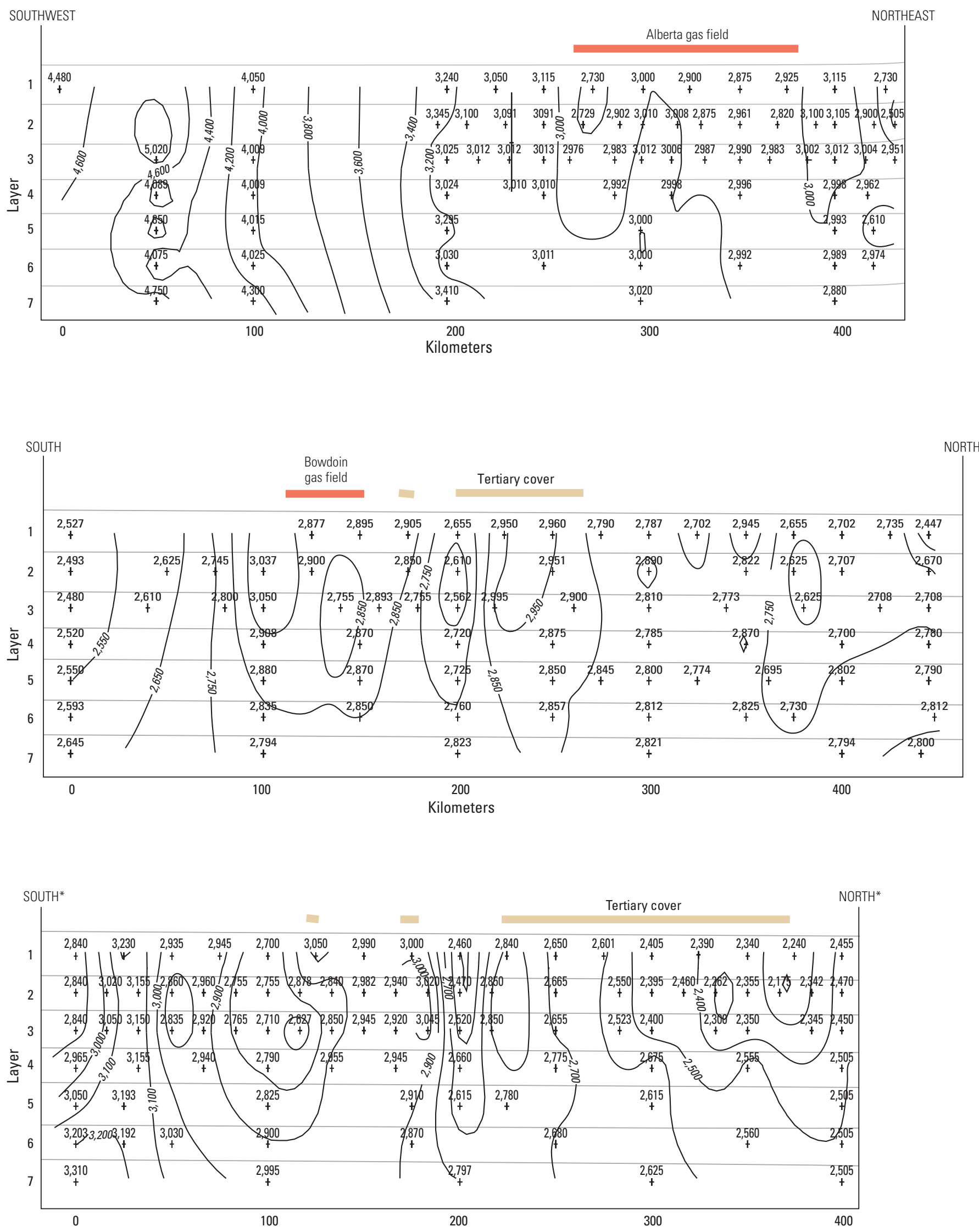


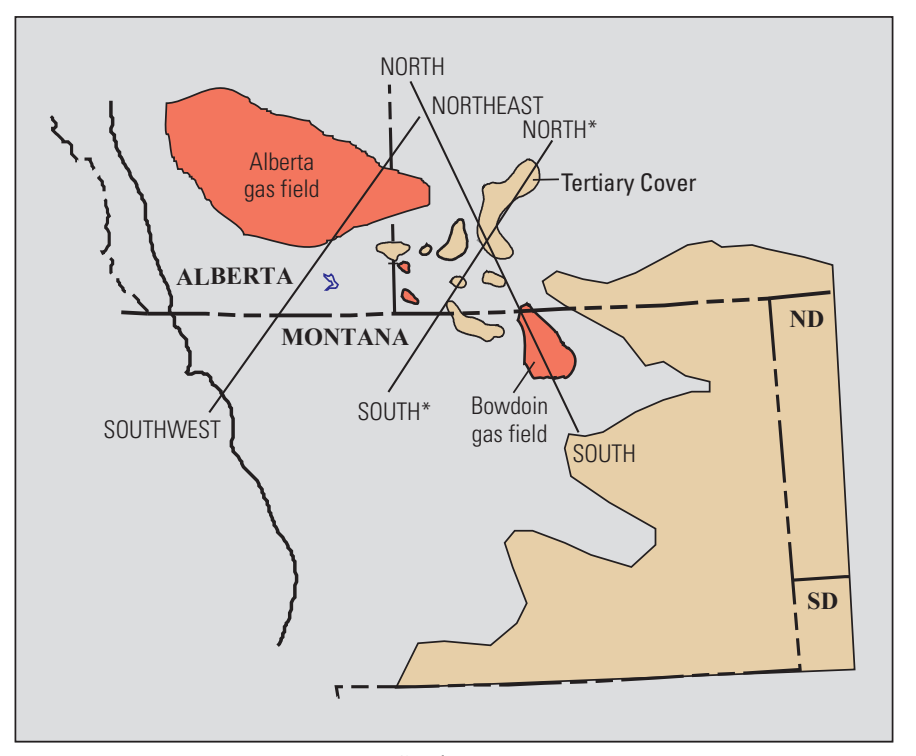

Study area

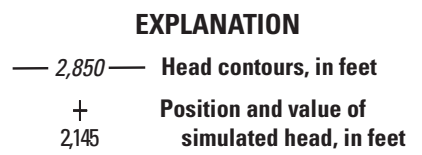

Figure 20 (above and facing page). Diagram of three, twodimensional cross sections of simulated hydraulic head through gas producing and Tertiary outcrop areas. Note that the head differential is greatest under the Tertiary cover remnant areas.

the Milk River have high flow capacity, even though the highpermeability zones are relatively thin. These values are well within the thickness differential between the top of Tertiary remnants and the surrounding topographic floor in the NGP.

To date, minor amounts of recoverable unconventional biogenic gas in Upper Cretaceous rocks in the study area have been produced under Tertiary covered remnants (fig. 22). Model results indicate that accumulations of gas that were originally beneath the remnants have been flushed (migrated) toward lower topographic and lower hydraulic head areas.

Field examples include Bowdoin, southeast Alberta, Big Stick, South Crane, Senate, and Wymark fields. The Bowdoin dome is not only a structural high, but is also breached through the Judith River Formation into the Claggett Shale. Therefore, there is no potential to push the gas away from the structure to overcome buoyancy forces. The model does not include areas that have large extents of Tertiary cover (southeast corner of fig. 22), because there is little topographic differential to create significant head gradients.

Lineaments may control the location of gas by helping to compartmentalize reservoirs and subtly adjust regional and subregional groundwater flow. Ridgley and others (2001) and Shurr (1984) showed that unconformity boundaries and stratigraphic thickness changes occur near lineaments. Figure 22 shows a tendency for current gas fields to align or position themselves between lineaments.

West Short Pine Hills (northwest South Dakota) biogenic gas field is an example of how topography can influence the distribution of gas in shallow shelf sand. Landforms of the West Short Pine Hills area consist of remnants capped with Pliocene age sandstones-Pierre Shale and Hell Creek Formation form the floor of the surrounding area. Topographic relief between the top and the floor is about $650 \mathrm{ft}(200 \mathrm{~m})$. The Shannon Member of the Eagle Sandstone underlies the area; the Shannon is a northwest-southeast trending offshore equivalent of the Eagle Sandstone. Biogenic gas accumulates in the Shannon in and near a north-trending structural nose with the remnant overlying the east limb of the structure. The original drilling focused on the north-trending structural nose but expanded off-structure to locate the limits of the sand trend. Wells drilled on the remnant are either dry or have minor production rates. The best production is in the flat, lowlying area parallel and adjacent to remnants.

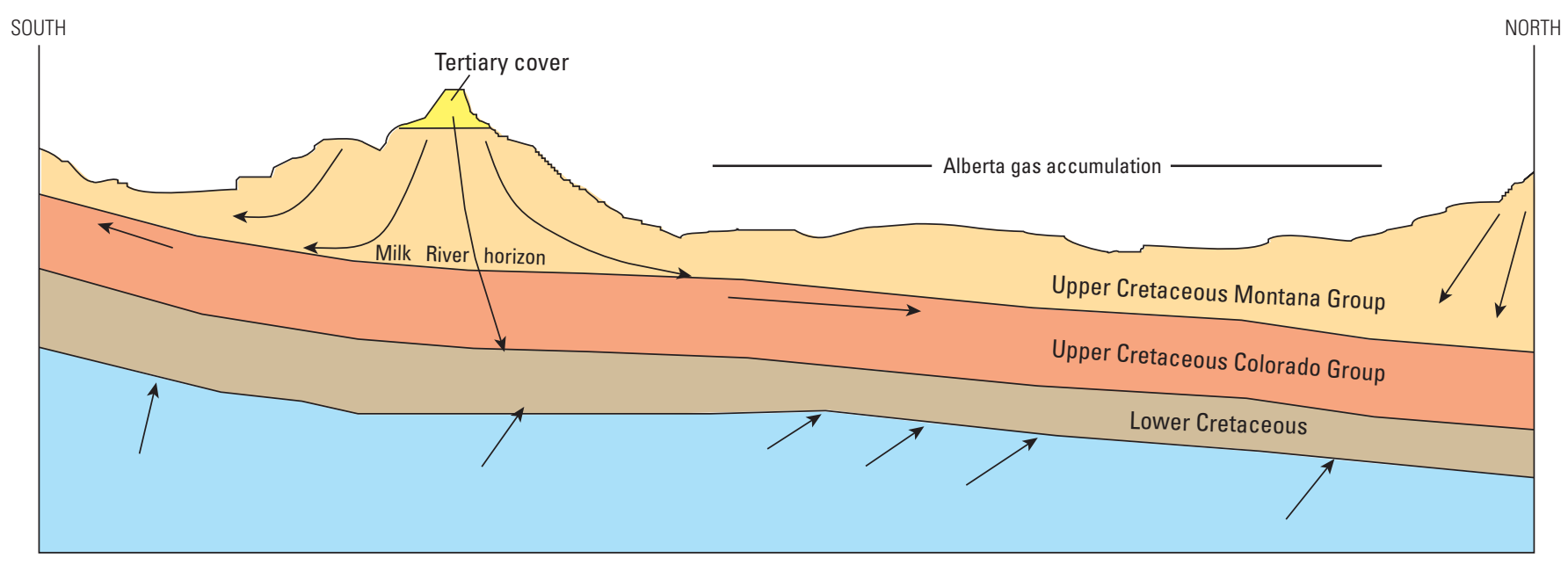

Figure 21. Diagram of a conceptual model of cross-sectional flow across southeast Alberta gas accumulation. Arrows are general indicators of flow direction and magnitude. Modified from Hitchon (1984). 
Table 5. Capillary pressures of the Milk River Formation, Alberta and Saskatchewan, Canada.

[Average depth to Milk River Formation under Cypress Hills: 2,500 ft. Minus sign, head > entry pressure of rock; Positive sign, head < entry pressure of rock; R35, 35 percent of pore throats are displaced in capillary pressure procedure; ft, feet; Psi, pounds per square inch; $\mu \mathrm{m}$, microns]

\begin{tabular}{|c|c|c|c|c|c|c|c|c|c|c|}
\hline $\begin{array}{c}\text { Sample } \\
\text { location }\end{array}$ & Operator & $\begin{array}{c}\text { Sample } \\
\text { depth } \\
\text { ft }\end{array}$ & $\begin{array}{l}\text { Measured } \\
\text { displacement } \\
\text { pressure } \\
\text { psi }\end{array}$ & $\begin{array}{l}\text { Measured } \\
\text { R35 } \\
\text { threshold } \\
\text { pressure } \\
\text { psi } \\
\end{array}$ & $\begin{array}{c}\text { Pore throat } \\
\text { diameter at } \\
\text { displacement } \\
\text { pressure } \\
\mu \mathrm{m} \\
\end{array}$ & $\begin{array}{c}\text { Pore throat } \\
\text { diameter at R35 } \\
\text { displacement } \\
\text { pressure } \\
\mu \mathrm{m} \\
\end{array}$ & $\begin{array}{l}\text { Initial } \\
\text { dispacement } \\
\text { pressure } \\
\mathrm{ft} \text { of wtr }\end{array}$ & $\begin{array}{c}\text { R335 } \\
\text { threshold } \\
\text { pressure } \\
\mathrm{ft} \text { of wtr }\end{array}$ & $\begin{array}{c}\text { Delta pressure } \\
\text { at initial } \\
\text { displacement } \\
\text { pressure }-2,500 \mathrm{ft} \\
\mathrm{ft}\end{array}$ & $\begin{array}{c}\text { Delta pressure } \\
\text { at initial R35 } \\
\text { displacement } \\
\text { pressure }-2,500 \mathrm{ft} \\
\mathrm{ft}\end{array}$ \\
\hline 10-12-1029W3 & Devon Canada & 1,845 & 12 & 295 & 8.92 & 0.36 & 28 & 681 & $-2,472$ & $-1,819$ \\
\hline 10-14MR-15-4W4 & Petro Canada & 1,288 & 45 & 725 & 2.38 & 0.15 & 104 & 1,675 & $-2,396$ & -825 \\
\hline $10-36-19-23 \mathrm{~W} 3$ & Murphy Oil & 1,391 & 670 & 1,800 & 0.16 & 0.06 & 1,548 & 4,158 & -952 & 1,658 \\
\hline $11-8 \mathrm{~T}-18-29 \mathrm{~W} 3$ & Apache Canada & 1,502 & 10 & 1,950 & 10.70 & 0.05 & 23 & 4,505 & $-2,477$ & 2,005 \\
\hline $14-34-13-28 W 3$ & Anadarko Canada & 1,330 & 10 & 70 & 10.70 & 1.53 & 23 & 162 & $-2,477$ & $-2,338$ \\
\hline 15-32MR-14-1W4 & Nexen Inc & 1,482 & 2.5 & 500 & 42.80 & 0.21 & 6 & 1,155 & $-2,494$ & $-1,345$ \\
\hline $3-24-15-28 W 3$ & Anadarko Canada & 1,450 & 9 & 195 & 11.89 & 0.55 & 21 & 450 & $-2,479$ & $-2,050$ \\
\hline $4-25-14-28 W 3$ & Anadarko Canada & 1,391 & 9.5 & 48 & 11.26 & 2.23 & 22 & 111 & $-2,478$ & $-2,389$ \\
\hline 4-3MR-15-3W4 & Petro Canada & 1,354 & 62 & 750 & 1.73 & 0.14 & 143 & 1,733 & $-2,357$ & -768 \\
\hline $6-22-17-28 \mathrm{~W} 3$ & Apache Canada & 1,371 & 20 & 600 & 5.35 & 0.18 & 46 & 1,386 & $-2,454$ & $-1,114$ \\
\hline $8-13-22-16 \mathrm{~W} 4$ & Encana Corp & 1,294 & 4,500 & 6,900 & 0.02 & 0.02 & 10,395 & 15,939 & 7,895 & 13,439 \\
\hline $8-13-22-16 \mathrm{~W} 4$ & Encana Corp & 1,365 & 3,800 & 6,800 & 0.03 & 0.02 & 8,778 & 15,708 & 6,278 & 13,208 \\
\hline $8-13-22-16 \mathrm{~W} 4$ & Encana Corp & 1,387 & 4,500 & 7,050 & 0.02 & 0.02 & 10,395 & 16,286 & 7,895 & 13,786 \\
\hline $8-13-22-16 \mathrm{~W} 4$ & Encana Corp & 1,406 & 220 & 1,800 & 0.49 & 0.06 & 508 & 4,158 & $-1,992$ & 1,658 \\
\hline $8-15-19-15 \mathrm{~W} 4$ & Encana Corp & 1,351 & 520 & 1,300 & 0.21 & 0.08 & 1,201 & 3,003 & $-1,299$ & 503 \\
\hline $8-15-19-15 \mathrm{~W} 4$ & Encana Corp & 1,449 & 1,500 & 5,000 & 0.07 & 0.02 & 3,465 & 11,550 & 965 & 9,050 \\
\hline Median values & & & 54 & 1,025 & 2.05 & 0.11 & 124 & 2,368 & $-2,376$ & -132 \\
\hline
\end{tabular}




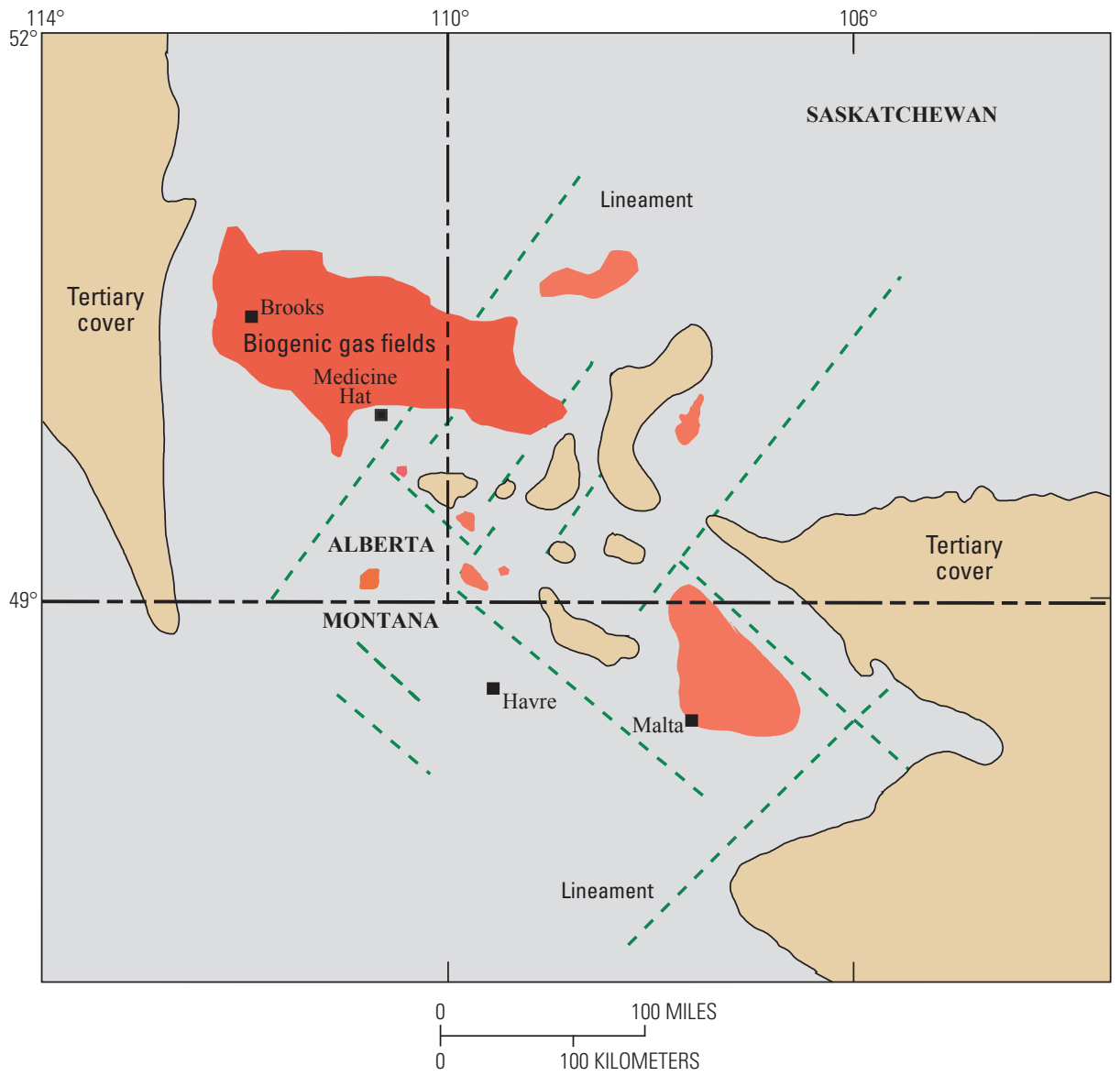

Figure 22. Map showing spatial relations between Tertiary covered remnants and economic biogenic gas fields. The concept does not differentiate between producing intervals. Note that (1) present-day economic gas accumulations are near but not under Tertiary remnants, and (2) lineaments appear to compartmentalize economic gas accumulations.

\section{Summary}

Numerical flow modeling showed that groundwater can alter the distribution of biogenic gas in Cretaceous stratigraphic units in parts of the NGP. Modeling results showed that hydraulic heads in high-permeability aquifers in structurally updip areas could negate buoyancy forces of gas in structurally downdip low-permeability rocks. In addition, gas that was generated in low-permeability shelf sandstones can neither overcome capillary or buoyancy forces nor migrate from low-permeability shales. Modeling indicated that areas with Tertiary covered topographic remnants create significant head (pressure) to negate capillary pressure of low-permeability sandstone and dislodge gas to areas of low head and velocity. Current gas accumulations are located some distance from the remnants, whereas only minor amounts of gas remain beneath remnants. Several factors are needed to accumulate biogenic gas in low-permeability Upper Cretaceous reservoirs in the NGP: (1) a permeability gradient from relatively low permeability, gas producing, organic-rich strata to relatively high permeability strata; this gradient enables gas (and water) to migrate into the low-permeability reservoir; (2) the updip hydraulic head in the reservoir must be greater than gas buoyancy and capillary forces of the low-permeability reservoirs; and (3) the reservoir has no updip high-permeability component; the downdip reservoir must have low permeability with no escape paths.

\section{Acknowledgments}

Thanks to several individuals from the USGS who contributed to this project, including Steve Condon, Chuck Spencer, Tim Hester, Neil Fishman, and Troy Cook. Thanks to Jennie Ridgley and Elisabeth Rowan, USGS, who helped conceptualize the flow system and gave valued advice and encouragement. Thanks to Krystal Pearson and Gary LeCain, USGS, whose technical reviews added clarity to the report. 


\section{References Cited}

Andrews, J.N., Drimmie, R.J., Loosli, H.H., and Hendry, M.J., 1991, Dissolved gases in the Milk River aquifer, Alberta, Canada: Applied Geochemistry, v. 6, p. 393-403.

Anna, L.O., 1986, Geologic framework of the ground-water system in Jurassic and Cretaceous rocks in the Northern Great Plains, in parts of Montana, North Dakota, South Dakota, and Wyoming: U.S. Geological Survey Professional Paper 1402-B, $36 \mathrm{p}$.

Belitz, K., and Bredehoeft, J.D., 1988, Hydrodynamics of Denver Basin: Explanation of subnormal fluid pressures: American Association of Petroleum Geologists Bulletin, v. 72 , no. 11 , p. 1334-1359.

Berkenpas, P.G., 1991, The Milk River shallow gas pool: Role of the updip water trap and connate water in gas production from the pool: Society of Petroleum Engineers Paper SPE 22922, p. 371-380.

Bredehoeft, J.D., Belitz, K., and Sharp-Hansen, S., 1992, The hydrodynamics of the Big Horn Basin: A study of the role of faults: American Association of Petroleum Geologists Bulletin 76, no. 4, p. 530-546.

Brown, D.L., 1978, Wrench-style deformational patterns associated with a meridional stress axis recognized in Paleozoic rocks in parts of Montana, South Dakota, and Wyoming: Montana Geological Society 23rd Annual Conference Symposium, p. 17-31.

Butler, R.D., 1984, Hydrogeology of Dakota aquifer system, Williston Basin, North Dakota, in Jorgensen, D.G., and Signor, D.C., eds., Geohydrology of the Dakota aquifer: National Water Well Association First C.V. Theis Conference Proceedings, p. 99-108.

Byrnes, A.P., 1997, Reservoir characteristics of low-permeability sandstones in the Rocky Mountains: The Mountain Geologist, v. 34 , no. 1, p. 37-48.

Case, H.L., III, 1984, Hydrology of Inyan Kara and DakotaNewcastle aquifer system, South Dakota, in Jorgensen, D.G., and Signor, D.C., eds., Geohydrology of the Dakota aquifer: National Water Well Association, p. 147-165.

Corbet, T.F., and Bethke, C.M., 1992, Disequilibrium fluid pressures and groundwater flow in the Western Canada sedimentary basin: Journal of Geophysical Research, v. 97, no. B5, p. 7203-7217.

Cramer, B., Poelchau, H.S., Gerling, P., Lopatin, N.V., and Littke, R., 1999, Methane released from groundwater: The source of natural gas accumulations in northern West Siberia: Marine and Petroleum Geology, v. 16, p. 225-244.

Downey, J.S., 1986, Geohydrology of bedrock aquifers in the northern Great Plains in parts of Montana, North Dakota, South Dakota, and Wyoming: U.S. Geological Survey Professional Paper 1402-E, $87 \mathrm{p}$.
Drimmie, R.J., Aravena, R., and Wassenaar L.I., 1991, Radiocarbon and stable isotopes in water and dissolved constituents, Milk River aquifer, Canada: Applied Geochemistry, v. 6, p. 381-392.

Fishman, N.S., Ridgley, J.L., and Hall, D.L., 2001, Timing of gas generation in the Cretaceous Milk River Formation, southeastern Alberta and southwestern Saskatchewan-Evidence from authigenic carbonates, in Summary of Investigations 2000, v. 1: Saskatchewan Geological Survey, Saskatchewan Energy and Mines, Miscellaneous Report 2000-4.1, p. 125-136.

Freeze, R.A., and Cherry, J.A., 1979, Groundwater: Englewood Cliffs, N.J., Prentice Hall, 604 p.

Freeze, R.A., and Witherspoon, P.A., 1966, Theoretical analysis of regional ground-water flow, Pt. 1, Analytical and numerical solutions to the mathematical model: Water Resources Research, v. 2, no. 4, p. 641-656.

Fuex, A.N., 1977, Use of stable carbon isotopes in hydrocarbon exploration: Journal Geochemical Exploration, v. 7, p. 155.

Gerhard, L.C., Anderson, S.B., LeFever, J.A., and Carlson, C.G., 1982, Geological development, origin, and energy mineral resources of Williston Basin, North Dakota: American Association of Petroleum Geologists Bulletin, v. 66, no. 8, p. 989-1020.

Gill, J.R., and Cobban, W.A., 1973, Stratigraphy and geologic history of the Montana Group and equivalent rocks, Montana, Wyoming, and North and South Dakota: U.S. Geological Survey Professional Paper 776, 37 p.

Hamblin, A.P., 1997, Stratigraphic architecture of the Oldman Formation, Belly River Group, surface and subsurface of southern Alberta: Canadian Petroleum Geology Bulletin, v. 45 , no. 2 , p. $155-177$.

Harbaugh, A.W., and McDonald, M.G., 1996, User's documentation for MODFLOW-96, and update to the U.S. Geological Survey Modular Finite-Difference Ground Water Flow Model: U.S. Geological Survey Open-File Report 96-485, $56 \mathrm{p}$.

Hendry, M.J., Schwartz, F.W., and Robertson, C., 1991, Hydrogeology and hydrochemistry of the Milk River aquifer system, Alberta, Canada: A review: Applied Geochemistry, v. 6, p. 369-380.

Hill, M.C., 1990, Preconditioned conjugate-gradient 2 (PCG2), a computer program for solving ground-water flow equations: U.S. Geological Survey Water Resources Investigations Report 90-4048, 43 p.

Hitchon, B., 1969, Fluid flow in the Western Canada sedimentary basin: Water Resources Research, v. 5, no. 1, p. 186-195.

Hitchon, B., 1984, Geothermal gradients, hydrodynamics, and hydrocarbon occurrences, Alberta, Canada: American Association of Petroleum Geologists Bulletin, v. 68, no. 6, p. 713-743. 
Levings, G.W., 1981a, Hydrogeological data from northern Great Plains area of Montana: U.S. Geological Survey Open-File Report 81-534, 1 sheet.

Levings, G.W., 1981b, Selected drill stem tests from the Northern Great Plains area of Montana: U.S. Geological Survey Open-File Report 81-326, 1 sheet.

Levings, G.W., 1982a, Potentiometric surface map of water in the Lakota Formation and equivalent units in northern Great Plains area of Montana: U.S. Geological Survey Open-File Report 82-563, 1 map sheet, scale 1:1,000,000.

Levings, G.W., 1982b, Potentiometric surface map of water in the Fox Hills-Lower Hell Creek aquifer in northern Great Plains area of Montana: U.S. Geological Survey Open-File Report 82-564, 1 map sheet, scale 1:1,000,000.

Levings, G.W., 1982c, Potentiometric surface map of water in the Eagle Sandstone and equivalent units in northern Great Plains area of Montana: U.S. Geological Survey Open-File Report 82-565, 1 map sheet, scale 1:1,000,000.

Lies, H., and Letourneau, J., 1995, Numerical modeling of the hydrodynamically trapped Milk River gas field, Western Canada: Journal of Canadian Petroleum Technology, v. 34, no. 10, p. 25-30.

Lillis, P.G., 2007, Upper Cretaceous microbial petroleum systems in north-central Montana: The Mountain Geologist, v. 44 , no. 1, p. 11-35.

Lobmeyer, D.H., 1980, Preliminary potentiometric surface map showing fresh-water heads for the Lower Cretaceous rocks in the northern Great Plains of Montana, North Dakota, South Dakota, and Wyoming: U.S. Geological Survey Open-File Report 80-757, 1 map sheet, scale 1:1,000,000.

Magara, K., 1972, Compaction and fluid migration in Cretaceous shales of Western Canada: Geological Survey of Canada, Department of Energy, Mines and Resources Paper $72-18,81 \mathrm{p}$.

Martin, I., and Young, G.C., 1991, The Medicine Hat gas field-100 years after discovery: Journal of Canadian Petroleum Technology, v. 30, no 5, p. 66-73.

Martini, A.M., Budai, J.M., and Walter, L.M., 1996, Microbial generation of economic accumulations of methane within a shallow organic rich shale: Nature, v. 383, p. 155-158.

Masters, J.A., 1979, Deep basin gas trap, Western Canada: American Association of Petroleum Geologists, v. 63, no. 2, p. $152-181$.

Maughan, E.K., 1982, Tectonic setting of the Rocky Mountain region during the late Paleozoic and early Mesozoic, in Proceedings of the Symposium on the genesis of Rocky Mountain ore deposits: Changes with time and tectonics: Denver Regional Exploration Geologist Society, Denver, p. $39-50$.
Meijer-Drees, N.C., and Mhyr, D.W., 1981, The Upper Cretaceous Milk River and Lea Park Formations in southeastern Alberta: Canadian Petroleum Geology Bulletin, v. 29, no. 1, p. 42-74.

Neuzil, C.E., 1986, Groundwater flow in low-permeability environments: Water Resources Research, v. 22, no. 8, p. 1163-1195.

Neuzil, C.E., and Bredehoeft, J.D., 1981, Measurement of insitu hydraulic conductivity in the Cretaceous Pierre Shale, in Doe, T.W., and Schwarz, W.J., eds., Well testing in low permeability environment: Lawrence Berkeley Laboratory Third Invitational Well-Testing Symposium, v. 1981, p. 96-102.

Neuzil, C.E., Bredehoeft, J.D., and Wolff, R.G., 1984, Leakage and fracture permeability in the Cretaceous shales confining the Dakota aquifer in South Dakota, in Jorgensen, D.G., and Signor, D.C., eds., Geohydrology of the Dakota aquifer: National Water Well Association First C.V. Theis Conference Proceedings, p. 113-120.

Nydegger, G.L, Rice, D.D., and Brown, C.A., 1980, Analysis of shallow gas development from low-permeability reservoirs of Late Cretaceous age, Bowdoin dome area: Journal of Petroleum Technology, p. 2111-2120.

O'Connell, S., 2002, The unknown giants-Low permeability shallow gas reservoirs of southern Alberta and Saskatchewan, Canada, in Innovative gas exploration concepts: Rocky Mountain Association of Geologists and Rocky Mountain PTTC Conference, October 2002, 18 p.

Rice, D.D., 1980, Coastal and deltaic sedimentation of Upper Cretaceous Eagle Sandstone: Relation to shallow gas accumulations, north-central Montana: American Association of Petroleum Geologists Bulletin, v. 64, no. 3, p. 316-338.

Rice, D.D., 1984, Widespread, shallow marine, stormgenerated sandstone units in the Upper Cretaceous Mosby Sandstone, central Montana, in Tillman, R.W., and Siemers, C.T., eds., Siliciclastic shelf sediments: Society of Economic Paleontologists and Mineralogists, Special Publication no. 34, p. 143-161.

Rice, D.D., and Claypool, G.E., 1981, Generation, accumulation, and resource potential of biogenic gas: American Association of Petroleum Geologists Bulletin, v. 65, no. 1, p. 5-25.

Rice, D.D., and Shurr, G.W., 1980, Shallow, low permeability reservoirs of northern Great Plains-Assessment of their natural gas resources: American Association of Petroleum Geologists Bulletin, v. 64, no. 7, p. 969-987.

Ridgley, J.L., 2000, Lithofacies architecture of the Milk River Formation (Alderson Member of the Lea Park Formation), southwestern Saskatchewan and southeastern Alberta-Its relation to gas accumulation, in Summary of investigations 2000 , v. 1: Saskatchewan Geological Survey, Saskatchewan Energy and Mines Miscellaneous Report 2000-4.1, p. $106-120$. 
Ridgley, J.L., Hester, T.C., Condon, S.M., Anna, L.O., Rowan, E.L., Cook, T., and Lillis, P.G., 1999, Reevaluation of the shallow biogenic gas accumulation, northern Great Plains, USA-Implications for similar gas resources in southeastern Alberta and southwestern Saskatchewan, in Summary of investigations 1999: Saskatchewan Geological Survey, Saskatchewan Energy and Mines Miscellaneous Report 99-4.1, p. 64-78.

Ridgley, J.L., McNeil, D.H., Gilboy, C.F., Condon, S.M., and Obradovich, J.D., 2001, Structural and stratigraphic controls on sites of shallow biogenic gas accumulations in the Upper Cretaceous Belle Fourche and Second White SpeckledGreenhorn Formations of southern Alberta, Saskatchewan, and northern Montana, in Anderson, D., ed., Gas in the Rockies: Rocky Mountain Association of Geologists Guidebook, p. 241-270.

Schroder-Adams, C.J., Adams, P.J., Leckie, D.A., Bloch, J., Craig, J., and Seif El-Dein, S.A., 1997, Upper Cretaceous Medicine Hat Formation and First White Speckled Shale in southeastern Alberta: Evidence for localized shallow water deposition: Canadian Petroleum Geology Bulletin, v. 45, no. 3 , p. $356-376$.
Shapiro, A.M., Margolin, J., Dolev, S., and Ben-Israel, Y., 1997, A graphical-user interface for the U.S. Geological Survey modular three-dimensional finite-difference ground-water flow model (MODFLOW-96) using Argus numerical environments: U.S. Geological Survey Open-File Report 97-121, 50 p.

Shurr, G.W., 1984, Geometry of shelf sandstone bodies in the Shannon Sandstone of southeastern Montana, in Tillman, R.W., and Siemers, C.T., eds., Siliciclastic shelf sediments: Society of Economic Paleontologists and Mineralogists Special Publication no. 34, p. 63-83.

Shurr, G.W., and Watkins, I.W., 1992, Basement control on Laramide deformation in the Powder River and Williston Basins and adjacent areas of the northern Midcontinent: Tectonics hierarchy in continental lithosphere: Proceedings of the International Conference on Basement Tectonics, v. 10, p. $432-433$.

Thomas, G.E., 1974, Lineament-block tectonics-WillistonBlood Creek Basin: American Association of Petroleum Geologists Bulletin v. 58, no. 7, p. 1305-1322.

Toth, J., 1963, A theoretical analysis of groundwater flow in small drainage basins: Journal of Geophysical Research, v. 68 , no. 16 , p. $4795-4812$.
Publishing support provided by:

Denver Publishing Service Center, Denver, Colorado

For more information concerning this publication, contact:

Center Director, USGS Central Energy Resources Science Center

Box 25046, Mail Stop 939

Denver, CO 80225

(303) 236-1647

Or visit the Central Energy Resources Science Center Web site at: http://energy.cr.usgs.gov/

This publication is available online at:

http://pubs.usgs.gov/sir/2010/5251/ 
